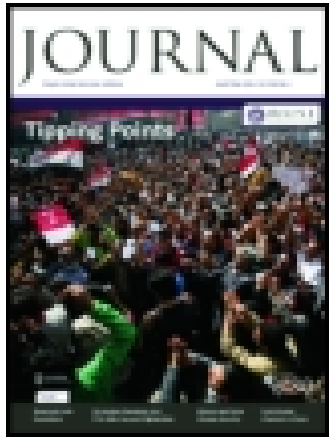

Royal United Services Institution. Journal

\title{
Von Löbell's Annual Reports on the Changes and Progress in Military Matters During 1897
}

\section{Major-General H. J. T. Hildyard Commanding 3rd Infantry Brigade C.B.}

To cite this article: Major-General H. J. T. Hildyard Commanding 3rd Infantry Brigade C.B. (1898) Von Löbell's Annual Reports on the Changes and Progress in Military Matters During 1897, Royal United Services Institution. Journal, 42:247, 1034-1073, DOI: 10.1080/03071849809417405

To link to this article: http://dx.doi.org/10.1080/03071849809417405

曲 Published online: 11 Sep 2009.

Submit your article to this journal $\widetilde{ }$

Џ Article views: 4

Q View related articles ¿ 


\title{
VON LÖBELL'S ANNUAL REPORTS ON THE CHANGLS AND PROGRESS IN MILITARY MATTERS DURING 1897.
}

\author{
Precis by dlajor-General H. J. T. HILDIARD, C.B., \\ Commanding Srat Infantey Brigate, Aldershot:
}

'THIS pubitication marks the twenty-fourth issue of these yearly' summaries of all that is of import or interest in the military matters throughout the world. Whenever a rupture occurs between two Powers which results in war, whether it be between nations such as Greece and 'Turkey as in 1897, or between the United States of America and Spain as in the current year, it is to the pages of Von Lobell's reports that reference is made for trustworthy information regarding the armed forces that it will be in the power of each combatant to place and maintain in the field.

This year, in addition to the exhatustive information recorded, which lias reference to Iuropean States, there are reports on the military cipabilities of the United States of America, Mexico, the Transvaal, and the Orange firce State, and also a slight complement to the preceding year's report on Afglianistan.

In next year's issue it is intended to present a retrospect of the changes that have taken place in army matters in the several States since the first appearance of this publication.

II. II.

REPORTS ON THE ARMED FORCES OF INDIVIDUAL STATES. GERMANi.

Piace Siringlh:-

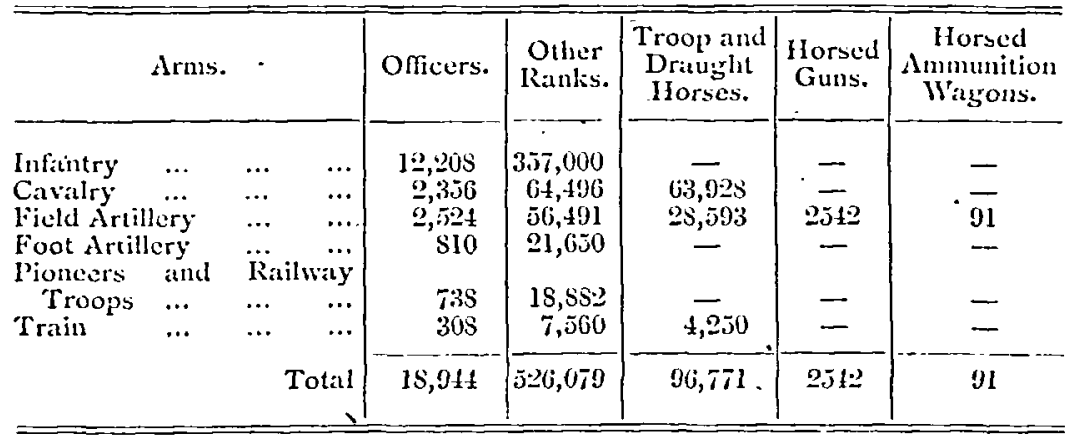

Only trained men are included in the numbers contained in this table. 
The peace strength of the several tactical units is the following:Infantry :-

86 battalions of regiments on the lower estabOfficers: MIen.

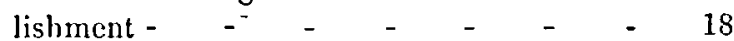

428 battalions of regiments on the medium establishment - $-\quad-\quad-\quad-18$

501

93 battalions of regiments on the higher

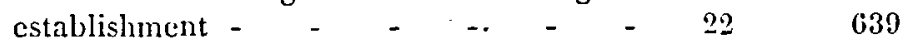

15 jiiger battalions on the lower establishment $\quad 22 \quad 614$

4 Jäger battalions on the higher establishment $\quad 22 \quad 679$

Cavalry :-

170 squadrons of regiments on the lower establishment - - -

235 squadrons of regiments on the

medium establishment -
60 squadrons of regiments on the higher establishment - $\quad$ - $\quad$ - $\quad 4 \quad 14$

Ficld Artillery :-

188 ficld batteries on the lower establishment - - -

235 field batteries on the - medium establishment -

24 field batteries on the higher establishment $=-\quad-4$ Officers. Men. Horses. $4 \quad 133 \quad 133$

$4 \quad 138 \quad 137$

$40 \quad 140$

573 
The following are some of the more important items of increase $i$ ii the establishments for $1897-98$ :-

\section{Officers.}

Prussia and the contingents administered by her :-

Infantry:-16 brigale commanders, 33 regimental commanders, 214 second lieutenants, 33 stperior surgeons, 33 surģeons.

Against this increase, there was a reduction of $6 t$ battalion commanders, 2 captains (1st class), 2 first lieutenants, and 60 assistant surgeons.

Caz'alry'-5 captains (1st class), 5 first lieutenants, 15 second licutenants for the detachment of Mounted Jägers.

Transport detachments for horsing foot artillery have been newly formed at Glogau and at Thorn respectively, and have been attached to the 6 th and 17th train battalions, which have each received an augmentation of a first licutenant.

In Bavaria there has been the following increase in the number of officers :-

Infantry. -2 brigade commanders, 2 regimental commanders, 2 ficld officers, 36 second lieutenants, 4 superior surgeons, and 6 surgeons.

There has been a reduction of 10 battalion commanders and 10 assistant surgeons.

Caz'aly'-1 captain (1st class), 1 first lieutenant, 3 second lieutenants.

The existing half detachment for horsing foot artillery has been increased to a complete detachment.

In Saxony there has been an increase to the infantry of 1 brigade commander, 3 regimental commanders, 22 second licutenants, 3 superior surgeons, and 3 surgeons. There has been a corresponding decrease of 6 battalion commanders and 6 assistant surgeons.

In Wurtemberg the increase has been 2 regimental commanders; 14 second licutenants, 2 superior surgeons, and 2 surgeons.

Formations, - Further progress has been made with the formation of the "Mounted Jäger detachnents," which is to be the designation henceforth of the "Meldereiter detachments."

There are now six of these, belonging respectively to the Guard Corps, the 1st, 14th, 15th, 17th, and 2nd Bavarian Army Corps. Each of them is attached to a regiment of cavalry, and is of the strength of a squadron of the regiment to which it is attached. The pirsonnel and horses are included in the establishment of the regiment concerned.

\section{Distribution of the naclly-formed Troops. \\ Prussial.}

5th Guard Infantry Brigacle Staff, jth lioot Guards Regiment, and 5th Grenadier Guards Regiment, Spandau.

73rd Infantry Brigade Staff and 146th Regiment, Königsberś; 147th Regiment, Insterburg. 
74th Infantry Brigade Staff and 148th Regiment, Stettin; 149th Regiment, Schneidemühl.

75th Infantry Brigade Staff and 1st Battalion 150th Regiment, Frankfurt a. d. O.; 2nd Battalion, Cüstrin; Staff and 1st Battalion 15lst Regiment, Wittenberg; 2nd Battalion, Neu-Duppin.

70th Infantry Brigade Staff and 1st Battalion 152nd Regiment, Magdeburg; ; 2nd Battalion, Zerbst; 153rd Regiment, Altenburg.

77th Infantry Brigade Staff and 155th Regiment, Ostrovo; 154th Regiment, Jauer.

78th Infantry Brigade Staff and 156th and 157th Regiments, Brieg.

79th Infantry Brigade Staff and 158th Regiment, Paderborn; 159th Regiment, Mühlheim a. d. Ruhr.

80th Infantry Brigade Staff and 161st Regiment, Trier; Staff and 2nd Battalion 160th Regiment, Bonn; 1st Battalion, Diez.

S1st Infantry Brigade Staff and 16 ?nd Regiment, Lübeck; 103rd Regiment, Neumünster.

82nd Infantry Brigade Staff, Hanover; 104th Regiment, Hameln; Staff and 1st Battalion 165th Regiment, Goslar; 2nd Battalion, Brandenburg a.H.

S3rd Infantry Brigade Staff and 166th Regiment, Hanau; 167th Regiment, Casscl.

Sth Infantry Brigade Staff, Carlsruhe; 169th Regiment, Lahr; 170th Regiment, Offenburg.

85th Infantry Brigade Staff and 172nd Regiment, Strasburg i.E.; 171 st Regiment, Bitsch.

80th Infantry Brigade Staff and 174th Regiment, Metz; 173rd Regiment, St. Avold.

87th Infantry Brigade Staff and 175 th and 176 th Regiments, Thorn.

Bazaria.

20th Infantry Regiment, Staff and 1st Battalion, Lindau; 2nd Battalion, Kempten; 3rd Battalion, Landsberg.

21st Infantry Regiment, Staff and 1st Battalion, Fürth; 2nd Battalion, Sulzbach ; 3rd Battalion, Eichstïdt.

22nd Infantry Regiment, Zweibrücken.

23rd Infantry Regiment, Landau; 2nd Battalion, Saargemünd.

9th Infantry Brigade, Landau.

10th Infantry Brigade, Metz.

11th Infantry Brigade, Neu-Ulm.

12th Infantry Brigade, Zweibrücken.

\section{Saxony:}

88th Infantry Brigade Staff and 177th Regiment, Dresden, 2nd Battalion, Königstein; 178th Regiment, Kamenz, 2nd Battalion, Zittau ; 179th Regiment, Leipzig; 2nd Battalion, Leisnig. 


\section{Iratrinlerg.}

127th Infantry Regiment, Ulm ; 180th Infantry Regiment, Tübingen ; 2nd Battalion, Gmünd.

Consequent upon the conversion of the 4 th battalions there were necessarily considerable modifications in the distribution of the previously existing formations.

Recriting. - The total number of men liable to be taken for service including both the alphabetical-lists of those becoming liable for the first time and the lists of those postponed in previous years was, in 1896, $1,575,488 \mathrm{men}$. This is an increase of $34,500 \mathrm{men}$ on the number for the preceding year.

The distribution of the total available was as follows:-

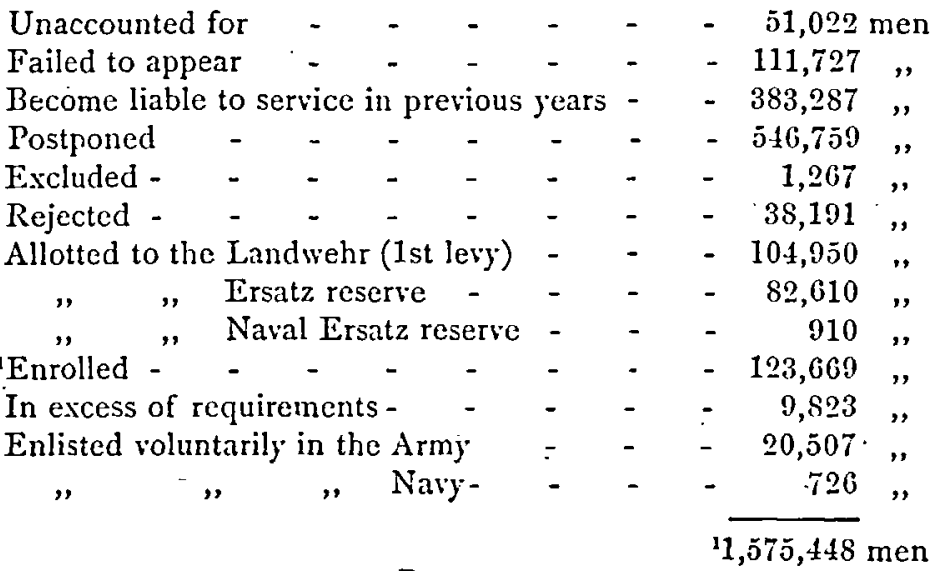

\section{Belgivar.}

The long deferred re-organisation of the Army, on the basis of obligatory personal service, has not as yet been effected.

In peace, as well as in war, the existing organisation provides for the formation of only 4 army divisions and 2 cavalry divisions, besides fortress troops.

In peace the infantry divisions, which have their headquarters at Ghent, Antwerp, Liège, and Brussels respectively, are composed each of 2 brigades. (The 3 rd division has 3 brigades.)

The 7 brigades, forming part of the 1st, 2nd, and 3rd divisions, consist each of 2 line regiments, with 6 active and 4 reserve battalions.

The 2 brigades of the 4 th division are composed 1 of 2 regiments of rifles, with 6 active and 4 reserve battalions; the other of 1 regiment each of rifles, grenadiers, and carabiniers, with together 10 active and 7 reserve battalions.

The 2 cavalry divisions are located at Brussels and Ghent respectively; the 1st division has 1 brigade detached to Namur, and the 2nd

1 These numbers are as given in Von Löbell (p. 12); but there appears to be an error somewhere of 100,000 men. The number enrolled in 1895 was 227,212 men, and for $1 \$ 96$ should probably be 223,669 instead of the number noted above. 
division has 1 at Mons. Each division has 2 brigades of 2 regiments, forming together 10 active and 2 depôt squadrons.

There are 2 brigades, the 1 st and 2 nd, of field ariillery, each of 2 regiments of 3 divisions, located at Ghent and Brussels respectively. The 2 nd and 4 th regiments have in addition 1 horse artillery battery.

The 1st and 3rd regiments consist each of 8 active, 2 reserve, and 1 depôt batteries; the 2 nd and 4 th regiments have 7 active, 3 reserve, and 1 depôt field batteries, and 2 horse artillery batteries.

There are also 2 brigades, the 3 rd and 4 th, of fortress artillery, each composed of 2 regiments. Each regiment is formed of 14 active, 2 reserve batteries; and 1 depót battery.

The engineer services are provided for by a regiment at Antwerp, composed of 3 active and 1 reserve battalions; of these, the staff and 2 companies of the 3 rd battalion are at Liegre and 2 companies at Namur.

There are further 7 companics and a depôt company of train, of which the headquarters are at Antwerp; the 3rd company is at the Beverloo camp, the 4 th at Brussels, and the 7 th at Brussels and Liege.

There are besides 4 companies of artillery and 5 of engineers for technical services.

On mobilisation 4 army divisions are formed, each consisting of 4 regiments of 12 battalions and a carabinier battalion; 2 squadrons, 8 field batteries (the 2nd and 3rd have only 7 ), 1 company of engineers and 1 train company, besides 4 ammunition columns, 2 supply columns, and auxiliary services.

The infantry has then to be expanded from its existing strength of 27,738 men by the addition of some 80,455 men drawn from 13 classes of the reserve; the cavalry receives 3,463 men, the artillery 18,035 men, and other arms and branches of the Service in like proportion. In all a strength of about 3,515 officers and $140,000 \mathrm{men}$ is anticipated.

If the several units be compared in a similar manner, it seems that the active battalion of the line will have 409 men on a peace establishment, whereas its war strength is 1,006 men. The reserve battalions having in peace a weak cadre of 27 men, will have to be increased to 806 men.

The active squadron has in peace 140 men and 130 horses; in war it has 160 men and 170 horses.

The artillery are even more unfavourably situated. The horse battery has in peace 114 men and 107 horses; in war 180 men and 216 horses. The field battery has in peace 92 men and 61 horses; in war 166 men and 154 horses. The reserve field battery, with a cadre in peace of $18 \mathrm{men}$ and 31 horses, has in war the same establishment as the active field battery. The active battery of fortress artillery has 68 men; for war it is raised to an establishment of 183 men.

\section{France.}

The total peace establishment of the Army for 1897 was fixed at 29,000 officers and 573,720 other ranks; the actual net strength was $\mathbf{2 8 , 0 6 6}$ officers and 529,800 men. In these numbers are included, how- 
ever, 732 officers and 24,860 men of the Gendarmerie and Republican Guard.

The estimates for 1898 were framed to provide for an increase of 151 officers and 12,542 men.

The most material changes effected during 1897 . were the formation, in accordance with the law of the 4 th of March, of 4 th battalions in the 145 sub-divisional infantry regiments, and the adoption of a new system for the field artillery.

The creation of the 145 new battalions that has been authorised is to be proceeded with gradually, according to the means and recruits available.

This new formation of the French infantry is a very material increase to the armed forces that will be made available in the first line; and it has this further advantage, that the new formations to be formed from the cadres complementaires will no longer have to be improvised upon mobilisation. A period of some years will be required before this measure is completed; but when it is, France will have at her disposal 145 more active peace battalions than she has now, which represents the infantry for six army corps.

The new battalions are to have an establishment of :-

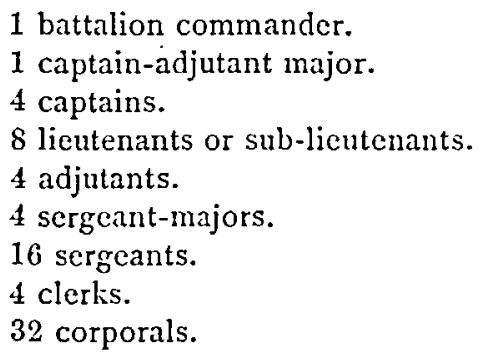

The number of privates has not been indicated.

According to the French military press, the formation of most of the 4 th battalions of the regiments of the 6 th and 15 th Corps was carried out in the autumn of 1897 . In each case from 2 to 4 companies were formed, each with a strength of 3 officers, 11 non-commissioned officers, and 100 men. During 1898 the formation of the 4 th battalions in the 1 st and 7 th Corps is to be effected.

When the measure has been carried out in all the army corps, the French infantry will have an increased peace establishment of about 50,000 men. The necessary number of recruits is available, for in the autumn of 1897 the number enrolled exceeded by 20,000 that of the preceding year.

It seems probable that eventually these new battalions may be utilised for the formation of larger bodies of troops.

The distribution of the battalions has only been fixed in the fol. lowing instances :- 
YON LÖBELL'S ANNUAL REPORTS.

$$
\begin{aligned}
& \text { 15th Army Corps Region:- } \\
& \text { 4th Battalion 50th Regiment - - Arles }
\end{aligned}
$$

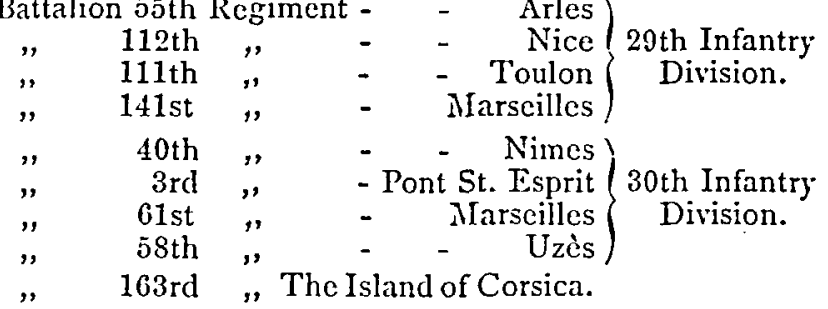

\section{6he Army Corts Region:-}

$$
\left.\begin{array}{rrrr}
\text { 4th Battalion 94th Regiment - } & - \text { Verdun } \\
& \text { 106th } & \text { Verdun-formed at } & \text { Challons }
\end{array}\right\} \begin{gathered}
12 \text { th Infantry } \\
\text { Division. }
\end{gathered}
$$

Artillery.-By a decree of the 15th January, the Sth Regiment is to consist in future of 12 field and 2 horse batteries (an increase of 1 field battery), and the 9th Regiment of 9 field and 2 horse batteries (a decrease of 1 field battery).

At the same time 2 batteries of foot artillery were transferred from the 7 th to the 10th Battalion.

On the 17th August, 4 new batteries of foot artillery were formed, and attached 1 each to the 7 th and 16th Battalions, and the other 2 to the 11th Battalion.

The following battalions of foot artillery now vary from the normal establishment of 0 battcries :-

$\begin{array}{rlll}\text { The 6th Battalion has } 9 & \text { batteri } \\ 7 \text { th } & \text { " } & 5 & \\ 11 \text { th } & " & 8 & 8 \\ 16 \text { th } & \text { " } & 9 & \end{array}$

Engineers.-The formation of a 20th Engineer Battalion for the new 20th Army Corps about to be formed, and of a Military Telegraph Corps of 6 companies is imminent.

Recruiting.-In 1896 the young men of the 1895 class were called up. These numbered 331,368 , being 5,841 less than the preceding year. There were also men postponed in 1894-46,627-and in 1893, 22,018 .

After deducting from the 1895 class those postponed and allotted to auxiliary services, there remained available 230,700 recruits for the Army. Of these, 69,438 were enrolled for an active scrvice of one year, and 161,262 for that of two to three years.

The number of recruits allotted to the infantry was $\rceil, 000$ more than it was in the preceding year.

In the course of the year 16,919 men joined the home army and 5,595 the troops in Algeria by voluntary engagement.

In Algeria the number of young men who became available for obligatory service was 5,311 , of whom 3,078 were enrolled. 
Composition of the Army by Annual Classes.-From the 1st November, 1897, to the 31st October, 1898, there belong:-

To the Active Army, the Annual Classes of 1896, 1895, and 1894 .

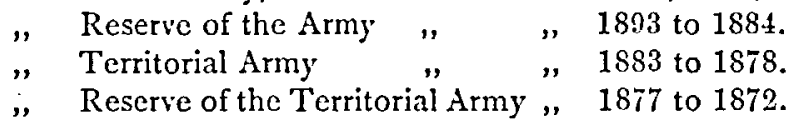

It appears from a debate that took place in the Chamber, that in the event of mobilisation the number of available horses fit for the requirements of service would be short by from 20,000 to 30.000 .

It has been stated by the Press that the total requirements in horses on mobilisation would amount to 483,045 , and the impossibility of obtaining the number of properly qualified horses required to augment the peace establishment has been pointed out.

Officers.-Since the establishment of the 15th February, 1896, there has been an increase of 289 infantry and 109 cavalry officers. There has been a reduction of 6 officers in the Artillery.

Development of Strategic Lines of Railicay.-A publication, entitled " Les Chemins de fer et la Mobilisation," appeared in the summer of 1897 , which contains remarkable and generally accurate information regarding the capabilities of the French railways for the purposes of mobilisation and war.

This part of the national defences has been organised with great care and technical knowledge, so that the utmost possible appears to have been done. In the period between 1881 and 1894, the increase in the total length of the available lines has been from 25,420 to 35,907 kilometres. Seven lines, double throughout and with steel rails, now lead to the eastern frontier.

The railway companies will be in a position, before the com-. mencement of mobilisation, to place 9,959 engines and 293,465 carriages (these numbers will have been still further increased during the last few years) at the disposal of the Minister of War. One hundred and six trains are required for the conveyance of an army corps, 29 trains for an infantry division of the usual composition, viz.:-12 battalions, 1 squadron, 6 batteries, with trains and columns. It is laid down that for the transport of the whole of the forces to the frontier, 2,014 locomotives and 64,488 wagons would be required; so there is a very material surplus in rolling-stock beyond the amount necessary.

The writer comes finally to the conclusion, that the railways are in a position to convey by the evening of the fifth mobilisation day $5,796,000$ men, a number considerably greater than France could produce in the event of war.

\section{ITALY.}

There are two establishments fixed for the Army in peace: the one lays down numbers of officers, men, and horses of the several arms that may not be exceeded ; the other indicates the average strength of these arms, or, in other words, the anticipated rationed strength. 
For all arms the following were the establishments for 1897-98:-

\begin{tabular}{|c|c|c|c|c|c|c|}
\hline Officers - & - & - & - & - & $\begin{array}{c}\text { Maximum. } \\
13,818\end{array}$ & $\begin{array}{r}\text { Average. } \\
13,392\end{array}$ \\
\hline Men & - & - & - & 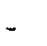 & 264,448 & 209,337 \\
\hline Oflicers' & rses & - & 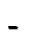 & -. & 10,123 & 9,79 \\
\hline Troop ho & & - & - & - & 38,434 & 36,18 \\
\hline
\end{tabular}

In war the twelve army corps of the Standing Army are each composed of 2 infantry divisions of 2 brigades (with 1 bersaglieri regiment), making 9 regiments $=27$ battalions infantry; 1 regiment cavalry $=6$ squadrons; 2 regiments, each of 2 divisions field artillery $=16$ batteries; 2 companies of engineers; 1 company for supply service; 1 sanitary company.

The Field Army is formed of the Standing Army and the Mobile Militia, which consists of all arms with the exception of cavalry.

The Standing Army consists of 14,397 officers, 511,758 other ranks, 94,201 public horses, 1,242 guns, and 16,248 horsed vehicles (including guns).

The Mobile Militia has 5,298 officers, 207,630 other ranks, 17,073 public horses, 360 horsed guns, and 3,450 horsed rehicles.

The special Sardinian Militia and the Territorial Militia are in addition to the above.

The latest information (June, 1896) in regard to the total numbers borne on the lists of the several categories gives the following results as regards men :-

\begin{tabular}{|c|c|c|c|c|}
\hline 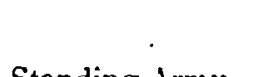 & With the & $\begin{array}{c}\text { On } \\
\text { Furlough. }\end{array}$ & Tot & $\mathrm{Pc}$ \\
\hline ing Army & 216,723 & 546,771 & 494 & 29 \\
\hline Mobile Militia - & 一 & 478,348 & 478,348 & $14 \cdot 38$ \\
\hline erritorial Mrilitia & 一 & $2,083,924$ & $2,083,924$ & $62 \cdot 63$ \\
\hline 100 & 216,72 & 43 & $3,325,766$ & $100 \cdot 00$ \\
\hline
\end{tabular}

Of the men of Territorial Militia, 07 per cent. (3rd category) are not trained at all ; a further considerable portion (2nd category) even of the Mobile Militia are only very little trained.

The situation is even worse as regards officers. In 1800 there were serving in the Active Army 14,414 officers, and there were allotted to that army 6,204 ersatz officers-an increase of 258 over the previous year. For the Mobile Militia there were 4,476 ersatz officers available, an increase of 167 over the previous year.

There were on the same date 5,490 officers belonging to the Territorial Militia, being a decrease of 140 as compared with the previous year. There were further 6,807 officers borne on the general list $a$ disposition, which includes retired officers; and, looking to the want of a proper control, it seems doubtful whether all those kept on the list are really still effective for service.

The Re-organisation Law of 1807. - This law gave legal sanction to many changes that ha $I$ already been effected. The following is a brief summary of its bearing upon the several portions of the armed forces. 
1. Standing Army.-One district command has been added, making 88 in all. 98 permanent district companies have been abolished and distributed amongst the infantry. The number of remount depots has been increased from 4 to 6 .

The changes that had been already effected before 1897 are the conversion of 6 field artillery batteries into a similar number of mountain batteries. The 6 batteries of field artillery now deficient are to be supplied on mobilisation by the MIobile Militia. Further, the separation of the coast and fortress artillery in independent battalions; the formation of a 5 th engineer regiment; the independence of the railway battalion, the strength of which has been increased from 4 to 6 companies.

2. Mobile Militia.-To consist of 51 infantry regiments of the line, 20 battalions of bersaglieri (an increase of 1), 38 Alpine companies (an increase of 16), 31 squadrons (to replace the 25 reserve squadrons previously cxisting), 63 field artillery batteries (an increase of 9$), 15$ mountain attillery batteries (an increase of six), 78 coast and fortress artillery companies (an increase of 34 ), 2.4 artillery train companies (an increase of 9 ), 54 engineer companies, and 4 engineer train companies. On the other hand, 13 sanitary companies and 13 supply companies are done away with, as is also the case in the Territorial Militia, for, in the event of war, the whole of the sanitary and supply personnel is to be allotted to the army of the first line.

3. Territorial Mililia. - The strength of this is fixed at 324 battalions of infantry (an increase of 4 ), 22 Alpine battalions ( 75 companies), 100 fortress artillery companies, and 30 engineer companies.

The redistribution of military districts, provided for by the same law, is as follows, the first place named after the number of each division is the staff quarters of the division:-

1st Army Corps (1st division): Turin, Pinerolo; (2nd division): Novara, Vercelli, Ivrea.

2nd Army Corps (3rd division): Alessandria, Casale, Voghera, Pavia; (4th division): Cuneo, Mondovi.

3rd Army Corps (5th division): Milan, Monza, Como, Lodi, Varese; (6th division): Brescia, Luco, Bergamo:

4th Army Corps (7th division): Placentia, Cremona, Parma, Reggio, Emilia; (8th division): Genoa, Savona.

5th Army Corps (9th division): Verona, Vicenza, Mantua; (10th division): Padua, Rovigo, Venice, Belluno, Treviso, Udine.

6th Army Corps (11th division): Bologna, Madena, Ferrara; (12th division): Ravenna, Farli.

7th Army Corps (13th division): Ancana, Pesaro, Mascrato; (14th division): Chieti, Teramo, Ascoli Piceno, Aquila, Salmona, Campobasso, Foggia.

8th Army Corps (15th division): Florence, Arezzo, Pistoia; (16th division): Leghorn, Sienne, Lucca, Massa. 
9th Army Corps (17th division): Rome, Frosinone; (18th division): Peruggia, Spoleto, Orvieto ; (25th division, Sardinia): Cagliari, Sassari.

10th Army Corps (19th division): Naples, Caserta, Gaëta, Benevento; (20th division): Salerno, Campagna, Avellipo, Nola.

11th Army Corps (21st division): Bari, Barletta, Lecce, Tarento, Potenza; (22nd division): Catanzaro, Reggio, Calabria, Cosenza, Castrovillari.

12th Army Corps (23rd division): Palermo, Girgenti, Trapani, Cefalu ; (24th division): Messina, Syracuse, Sattanisctta, Catania.

Artillery.-The territorial distribution is different in the case of the artillery, the superior commands of which are grouped in eight centres in the following manner:-

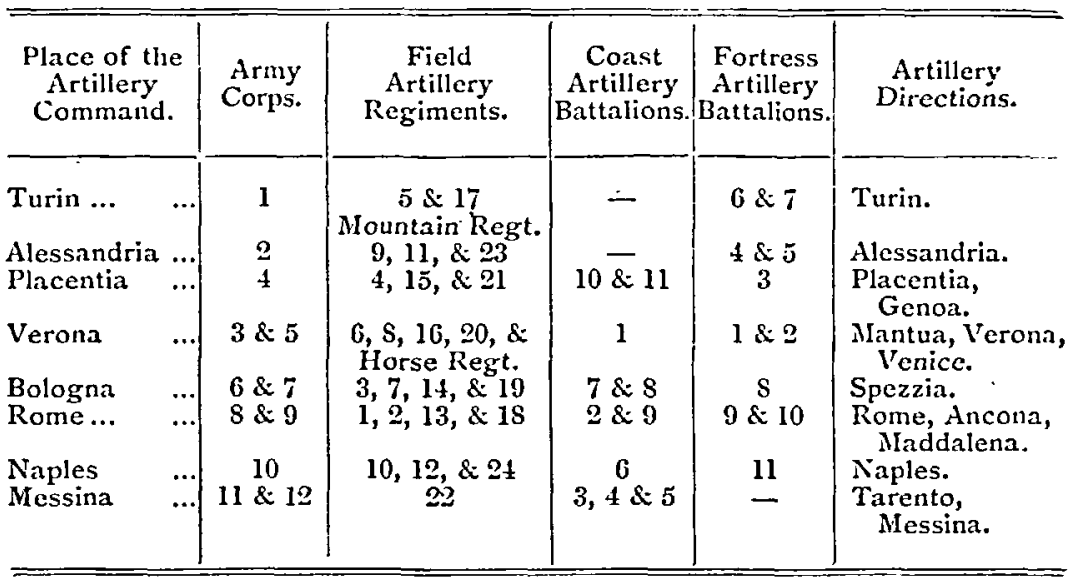

Engineers.-The distribution of this arm is the following:-

\begin{tabular}{|c|c|c|c|}
\hline $\begin{array}{l}\text { Engineer } \\
\text { Command. }\end{array}$ & $\begin{array}{l}\text { Army } \\
\text { Corps. }\end{array}$ & Directions. & Sub.Directions. \\
\hline $\begin{array}{ll}\text { Turin } & \ldots \\
\text { Venice } & \cdots \\
\text { Genoa } & \cdots \\
\text { Spezzia } & \cdots \\
\text { Rone } & \cdots \\
\text { Naples } & \cdots\end{array}$ & $\begin{array}{c}1 \& 2 \\
3 \& 5 \\
4 \\
6 \& 8 \\
7 \& 9 \\
10,11 \& 12\end{array}$ & $\begin{array}{lr}\text { Turin, Alessandria, Milan } \\
\text { Verona, Venice ... } & \ldots \\
\text { Placentia, Genoa... } & \ldots \\
\text { Bologna, Florence, Spezzia } \\
\text { Ancona, Rome } \ldots & \ldots \\
\text { Naples, Bari, Palermo } & \ldots\end{array}$ & $\begin{array}{l}\text { Novara, Cuneo. } \\
\text { Brescia, Padua. } \\
\text { Ravenna, Leghorn. } \\
\text { Chieti, Perugia, Cagliari. } \\
\text { Salerno, Catanzaro, } \\
\text { Tarento, Messina. }\end{array}$ \\
\hline
\end{tabular}

Infantry Organisation.-On the 1st January, 1898, every regiment of infantry and bersaglieri had to form a depot. After the changes of garrison had been carried out in the February and March following, 22 infantry and 5 bersaglieri regiments had their depots (including the stores of clothing and arms for mobilisation) away from the regiment, though most of them were in its neighbourhood.

Training.-Having regard to the small proportion of men, not belonging to the Active Army, called up for training in 1896 , the number 
was exceptionally large in 1897. More than 100,000 men underwent a course of training, the duration of which varied from fifteen to thirty days. The object of calling out so many men was not solely to freshen up their military training, but also with a view to strengthening the troops participating in the manœuvres, to forming a separate division of. Mobile Militia for the great manouvres, to affording a trial of the coast-defence service, and to making as many men as possible familiar with the 6.5 -millimetre rifle.

The men who were trained for fifteen days belonged to the Territorial Militia of seven districts of the 8th Army Corps and were those destined to form coast-defence companies. Those trained for twenty days and twenty-five days respectively belonged in part to men of the reserve of the Standing Army, part to the Mobile Militia and the rest to the Territorial Militia.

The only men up for the full period of thirty days (in some cases thirty-five days) werc the non-commissioned officers in each case; and the men belonging to the reserve of the Alpine troops (1872 class).

\section{Mexico.}

The promulgation of the law of $189^{\circ}$, for the organisation of the armed forces, has brought into unusual prominence the military capabilities of this State.

In peace the Standing Army consists of the units specified below; until mobilisation, formed bodies larger than battalions and regiments are not constituted:-28 battalions of infantry of 4 companies, 12 cadre battalions of infantry of 2 companies, 2 regional infantry battalions of 2 companies, 7 regional infantry companies, 1 battalion of pioneers of 4 companies, 1 battalion of invalids, 14 cavalry regiments of 4 squadrons, 8 cavalry cadre regiments of 2 squadrons, 2 regional squadrons, 1 squadron mounted police, 4 battalions of field artillery of 4 batteries, 1 battalion of machine-gun artillery of 2 companies, 1 park squadron, 1 train squadron.

The peace establishment is :-

\begin{tabular}{|c|c|c|c|c|c|}
\hline Infantry & - & $\begin{array}{c}\text { Officers. } \\
-\quad 1,286\end{array}$ & $\begin{array}{c}\text { Non-com. } \\
\text { Officers. } \\
3,326\end{array}$ & $\begin{array}{c}\text { Men. } \\
16,651\end{array}$ & $\begin{array}{c}\text { Horses } \\
\text { and mules. } \\
1,363\end{array}$ \\
\hline Cavalry & - & - $\quad 603$ & 1,849 & 5,989 & 9,257 \\
\hline Artillery & - & 228 & 722 & 1,867 & 2,205 \\
\hline Engineers & - & 55 & 150 & 585 & 234 \\
\hline
\end{tabular}

In war the strength is :-

$\begin{array}{llllllrr}\text { Infantry. - } & - & - & - & - & - & 1,600 & 32,000 \\ \text { Cavalry - } & - & - & - & - & - & 900 & 8,000 \\ \text { Artillery - } & - & - & - & - & - & 400 & 3,500 \\ \text { Engineers } & - & - & - & - & - & 100 & 1,000 \\ \text { Reserves of all arms - } & - & - & - & \underline{600} & 100,000 \\ \text { Total } & - & - & - & - & - & 3,600 & 144,500\end{array}$


To these numbers will have to be added the auxiliary forces which the several States of the federation are able to dispose of. The new organisation of these is in course of preparation, and will later on be of the greatest use to the Army; the strength likely to be made available cannot as yet be estimated.

The reserves consist of the National Guards of the several States (there are twenty-seven), and of the one federated district associated with them. Such permanent troops as exist in the several States not belonging to the National Guard are to form the first quota towards. completing the Army on mobilisation.

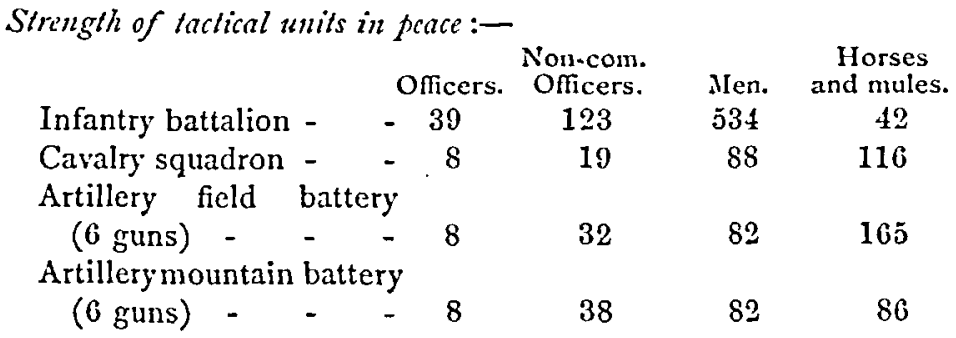

Except that the infantry battalion has in war 822 men and batteries have 110 men each and about 30 more horses, the establishments in peace and war are for all practical purposes identical.

The 12 cadre battalions have 11 officers, and each of their 2 companies has $71 \mathrm{men}$.

The 2 regional battalions garrison Yucatan and Tampico, and are named after those places. Their strength is each 12 officers, 30 noncommissioned officers, 12 musicians, 147 privates.

The 7 regional companies are distributed 1 each in Campeche, Tabasco, Acapulco, Coatzacoalcos, Salina Cruz, and 2 in North California. They bear the names of their garrisons, and vary in their. establishment from 136 to $86 \mathrm{men}$, including non-commissioned officers. Together they number 38 officers, 164 non-commissioned officers, 28 musicians, and 648 privates.

The squadron in the cavalry cadre regiments consists of 4 officers, 14 non-commissioned officers, 3 trumpeters, and 54 troopers, with 4 officers, and 71 troop horses.

The 3 regional squadrons are located in the districts of Sonora, Chihuahua, and North California respectively, and bear the names of these places. Fach of these squadrons has 6 officers, 1 telegraph officer with two assistants, 17 non-commissioned officers, 3 trumpeters, 56 troopers, and 3 train soldiers; also 7 officers' horses, 78 troop horses, and 8 mules.

The mounted military police consists of 1 squadron, numbering 8 officers, 20 non-commissioned officers, 4 trumpeters, 85 men, 2 drivers; also 8 officers' and 111 troop horses, and 10 mules.

The 4 battalions of field artillery have together 104 guns. Each battalion is formed, in peace, of 2 field and 2 mountain batteries, each of 
6 guns and 2 horse artillery guns. In case it should seem desirable, the 8 horse artillery guns can be formed into a battery and attached to the cavalry.

The machine-gun artillery consists of 2 companies, each consisting of 6 officers, 29 non-commissioned officers, 4 musicians, 36 gumners, 41 drivers; with 12 machine guns, 6 officers' lhorses, 15 troop horses, and 88 mules.

Molilisalion.-The commanders and staff are not appointed beforchand. Brigades of cavalry and infantry would be constituted of 3 regiments or battalions each. Divisions would consist of 3 brigades; army corps of 3 divisions; and an army command of from 2 to 3 army corps. Each staff, from the brigade upwards receives a cavalry escort of from 10 to 18 , or 27 troopers.

On mobilisation the 28 infantry battalions are raised to war strength by ti.e addition of 42 men per company.

The 12 cadre battalions are raised to the normal peace strength.

In the cavalry of the line 8 men and 8 horses are added to each regiment; in the cadre regiments $10 \mathrm{men}$.

Each field and mountain battery is augmented to 8 guns; the machinegun artillery to 32 machine guns.

\section{Montenegro.}

The following new territorial distribution forms the framework for formations in war :-

1st brigade district. Staff Quarters Niegusch - - - 7 battalions.

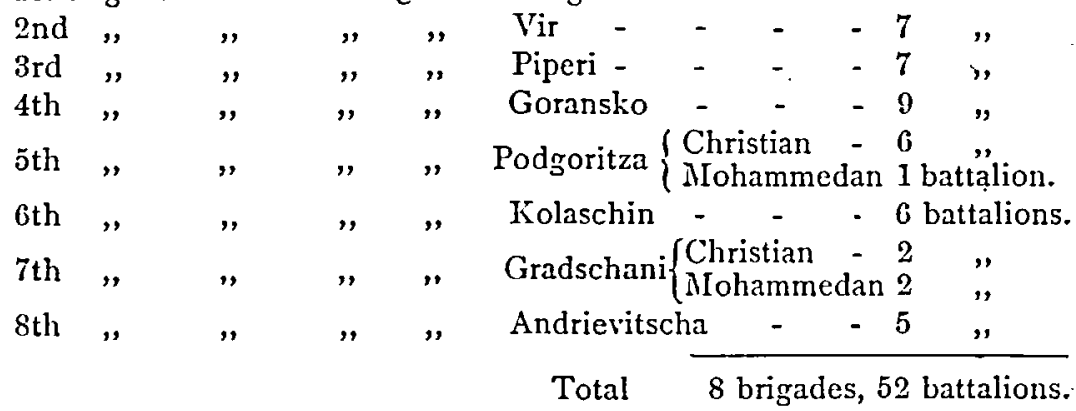

The formation of the higher units is not definitely fixed beforehand. Their constitution would be based on the principle of 2 battalions forming a brigade, each of which would have attached to it 4 mountain and 2 field guns.

The number of men liable for service has been estimated variously. at 37,250 and 43,500 , of whom from 2,500 to 3,500 are Mohammedans. The instructional cadre battalion, established in 1896 , affords a 4 months' training to 1,300 men yearly. These are selected by lot from those liable to service who are 25 years of age. $U p$ to the present time $2,300 \mathrm{men}$ have been trained in this manner. 


\section{Austria-Hungaky.}

The year 1897 did not witness any far-reaching changes in the organisation of the Army.

In April a third inspector-general of troops was nominated in the person of the former commander of the 3rd Corps.

In May a 4th Landwchr cavalry brigade conmand was established and located at Debreczin.

In October, a 16th company was added to each of the 4 BosniaHerzegovina infantry regiments; this completes the formation of these regiments.

Cazalry.-New regulations were issued respecting the organisation of the regular cavalry, in which the changes introduced during recent years were embodied. The regular cavalry consists of 42 regiments, of which 15 pre Dragoons, 16 Hussars, and 11 Lancers; these are named after the color.s-in-chief of the regiment and have also a consecutive number.

The regiments are as a rule located territorially, and are grouped in brigades, and also in part in divisions, of which five are formed.

In peace each regiment is divided into the regimental staff and 2 divisions, each of 3 field squadrons and 1 ersatz squadron. There are also 1 pioneer sub-division and 1 telegraph patrol with each resiment. The regiment is commanded by a colonel, the 2 divisions by a licutenant-colonel and major respectively. The 6 field squadrons have 30 officers, 871 mounted men, and 126 dismounted men of other ranks.

The ersatz cadre consists of 4 officers and 23 men, 6 of whom are mounted. The total of the entire regiment is 45 officers and officials, 1,043 other ranks, and 973 horses.

As compared with the previous establishment, this shows an increase of 2 subaltern officers, 2 telegraphists (mounted sub-division leaders), and 2 mounted sanitary assistants. The number of non-commissioned officers is increased by 25 corporals and 26 patrol leaders, an equivalent reduction being made in the number of troopers.

The men and their horses belonging to the pioneer sub-division are on the establishment of the field squadrons in peace; in war a packhorse is added for the transport of explosives.

The telegraph patrol consists of 2 sub-division leaders and 2 orderlies; its duties are to transmit reports and orders by telegraph.

The Hungarian Landwehr cavalry has also been given a revised constitution, which includes the changes carried out in 1896 , by the creation of 2 patrol-leaders per squadron, the addition of 2 sanitary assistants to the regimental staff, and the increase from 5 to $\delta$ of the squadron pioneers.

This cavalry consists of 10 Hussar regiments, having each a regimental staff, 2 divisions (en cadre), and 1 ersatz cadre; during the autumn exercises and on mobilisation 1 pioneer sub-division and 1 telegraph patrol are formed. 
The regiments are grouped in brigades, and are as a rule located in the areas in which they would be completed.

The establishment of a squadron, in peace, is 4 officers, 65 men, and 30 horses. From October to the end of January they have in addition 10 remounts, and from February to September $2 \frac{1}{4}$ remounts. The permanent establishment of the whole regiment is 39 officers, 420 men, and 259 horses; in addition, from October to January there are 60 remounts, and from February to September 145.

\section{ROUMANIA.}

A project for the alteration of the organic law as regards the terms of service was presented. Its object is to extend the liability to active service, while lengthening the periods in the reserve and militia. The numerous cases in which hitherto exemption from active service was permissible have, with few exceptions, been done away with, and instead of exemption only a diminution of permanent service during the first year is to be allowed.

The period of active service with the colours for the permanent troops of the line is fixed at 3 ycars, for the cavalry serving periodically at 4 years, and for the infantry 5 years.

The term of service in the reserve, which has hitherto lasted until the completion of the 30 th year of age, has been extended to the 36 th year inclusive. Similarly liability to serve in the militia is prolonged from the 36 th year until the end of the 45 th year of age.

Russia.

\begin{tabular}{|c|c|c|c|c|c|c|c|}
\hline Peace Strengt & th in & & & d the $\mathrm{Ca}$ & casus. & Elsetv & iere. \\
\hline Infantry & - & - & 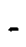 & 497,000 & nen. & 66,000 & men \\
\hline Cavalry & - & & 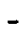 & 109,000 & , & 10,000 & \\
\hline Artillery & - & 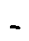 & - & 107,000 & " & 8,000 & \\
\hline Engineers & - & - & & 21,000 & " & 3,000 & \\
\hline Administra & ation & - & & 34,000 & $"$ & 5,000 & \\
\hline T & & & & 68,000 & & 92,000 & \\
\hline
\end{tabular}

Together 36,000 officers, and in round numbers 860,000 men, not including the frontier guards, convoy escorts, military police, and fleet; but including Cossacks, Finns, native Caucasian troops and militia.

War Establishment:-

Field troops.

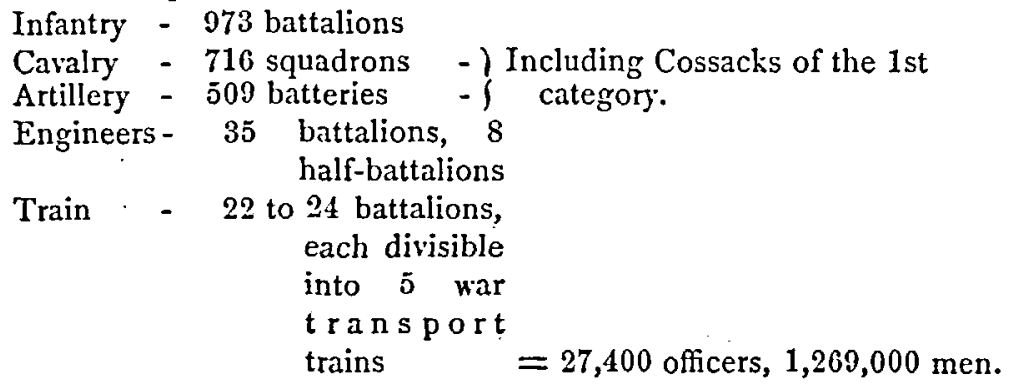


Reserze troops.

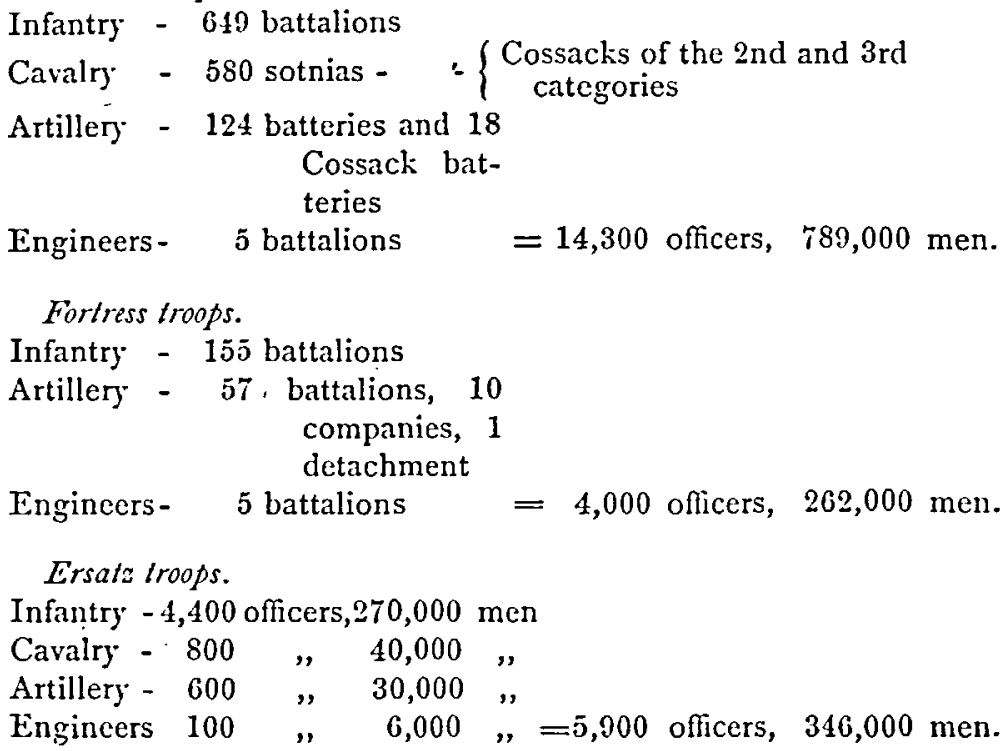

Reichswehr.

Infantry $-9, \tilde{0} 00$ officers, 686,000 men

Cavalry - 350 " 22,000,

Artillery - $450 \quad$ " $28,000 "$,

Engineers $100 \quad " \quad 4,000 \quad,=10,400$ officers, 740,000 men.

Frontier Guards - - - - 1,000 " 34,000 "

$\overline{63,000}, \overline{3,440,000}$,

Infantry Formations. - The most important change, though it had been long foreseen, was the order for the formation on the 1st (13th) January, 1898, of 2 new army corps. These are to be numbered 20 and 21, the first being formed in the military district of Vilna, and the other in that of Kicf. The staff quarters of the 20 th Corps are fixed at Riga, and of the 21st at Kieff. These army corps are formed from the reserve infantry brigades already existing in these districts, each of which was previously composed of 4 regiments of 2 battalions. These 4 brigades have now been constituted as 2 complete divisions, composed of 4 regiments of 4 battalions. The other 2 divisions, 1 for each new army corps, have been taken from previously existing army corps. Thus the 20th Army Corps has received from the 3rd Army Corps (Riga) the old 29th Division and the new 45th Division; the 21st Army Corps has been made up of the 33rd Division from the 9th Army Corps (Kieff), and the new 42nd Division.

The places of the 29 th and 33rd Divisions in the 3rd and 9 th Army Corps respectively have been taken by the 43rd and 44th new Divisions.

Cavalry.-By an order of the 8th (20th) September, a 3rd independent brigade, composed of the newly-formed regiments Novo Alexandrovsk 
No. 53, staff at Vlozlavek, and Novo Mirogrodsk No. 54, staff at Kolo, has been added to the 2 previously existing.

The 3rd guard cavalry brigade, which has belonged hitherto to the 2nd guard cavalry division, but has been located in Warsaw, has now been combined with the newly-formed 3rd independent brigade, referred to above, in a new cavalry division.

This combined division has been united with the independent 15th cavalry division (Warsaw District) in a new cavalry corps, designated the 2nd, with its staff quarters at Warsaw. The previously existing cavalry corps is henceforth to be designated the 1st.

Artillery.-The field artillery has been greatly augmented during 1897 , and changes have been made concurrently in its organisation.

Altogether 68 light batteries and 1 mountain battery have been newly formed. Of these, 24 have been allotted to 4 new field artillery brigades of 6 batteries; 2 guard batteries to the guards rifle brigade, which has hitherto been without artillery; 3 grenadier batteries as the 3rd division with the grenadier brigade; 2 batteries in augmentation of the previously existing artillery ( 6 batteries) of 16 of the brigades; 2 battcries for the Caucasus rifle brigade, which loses 1 of its 2 mountain batteries; 2 light reserve batteries and 1 mountain reserve battery for the newly formed Caucasus reserve artillery brigade, which also receives a light battery.

The batteries to be raised are, in the case of the 39th Brigade, to have in peace 8 horsed guns and 2 ammunition wagons, in 7 brigades there are to be 8 horsed guns, and the rest. are only to have 4 guns horsed.

A portion of the mountain batteries existing in the old brigades Nos. 20,21 , and 39 is to be converted into light batteries, and another portion to be distributed more widely amongst the brigades. The organisation of the Caucasus artillery brigades is to be in divisions of 2 to 3 batteries.

The strength and organisation of the European and Caucasus artillery, resulting from the changes described, are from the 1st January, 1898, the following:-2 artillery brigades, the 3 rd guards and 1 st grenadier brigades, have each 9 batteries in 3 divisions; 21 brigades have each 8 batteries formed in 3 divisions, the 1st and 2nd of which each consists of 3 batteries, the 3 rd of 2 batteries.

The 4 Caucasus artillery brigades have each 7 batteries, 6 of which are formed in 2 divisions of 3 batteries; the 7 th stands alone and is a mountain battery.

All the other 25 guard, grenadier, and field artillery brigades, including the 4 newly formed in 1897, have each 6 batteries in 2 divisions of 3 batteries each.

The artillery with the various rifle formations includes 1 division of 2 batteries with the guards rifle brigade; 5 divisions of 3 batteries for the 5 European rifle brigades; 1 division composed of 2 light batteries and 1 mountain battery for the Caucasus rifle brigade.

There is further 1 Finland regiment of 4 batteries. 
Reserve Artillery Brigades. - 6 European brigades of 6 batteries and 1 Caucasus brigade of 3 light batteries and 1 mountain battery. There are also 1 reserve cadre battery and 2 ersatz battcries.

The Asiatic artillery and mortar batteries remain unchanged.

The most noticeable of these new formations, which by their number alone are remarkable, is that of the 4 new field artillery brigades, Nos. $4 ?$, 43,44 , and 45 . Following immediately on the old 41 ficld artillery brigades, they are like these allotted to the $4 \mathrm{new}$ infantry divisions bearing the same numbers.

These changes in organisation also exercise a material influence upon the state of the reserve artillery in rear. Besides the previously existing 6 reserve artillery brigades, a Caucasus reserve brigade of 4 batteries has been formed. This will allow of the reserve brigades (in war, divisions) still existing as such, being provided with a stronger proportion of artillery than formerly. In place of cach reserve division of the first order having 4 batteries, it will now have 6 .

The number of previously existing mountain batteries has been decreased, their places being taken by light field batteries: the whole of the new batteries are of this nature. Excepting in Asia, mountain batteries only exist now in the 13th Artillery Brigade, the 4 Caucasus brigades, and the artillery division with the Caucasus rifles. The further reduction of the number of mountain batteries is contemplated, and an order of the 9th August, 1897, provides that the existing mountain artillery regiment (in peace 3 , in war 6 batteries) in Kief is to be abolished on the 1st January, $1899 ; 2$ mounted mountain batteries are to be formed in its place.

Flying parks (in war, park brigales) have been formed for the new 42nd, 43rd, 44th, and 45th Ficld Artillery Brigades. The artillery brigades to be formed only upon the mobilisation of the reserve artillery do not receive flying parks, but 7 reserve artillery parks are to be formed in peace in place of the "mobile parks," which have been done away with. The single East Siberian park previously existing has been expanded into 2. In war they become the 1st and 2nd East Siberian Park Brigades respectively.

By an order of January, 1897, a Caucasian siege artillery battalion of 4 companies has been formed. The battalions of fortress artillery at Sveaborg, Kovno, Assovjetz, Warsaw, Novogeorjevsk, Ivangorod, and Zegrsze have been placed on an increased peace establishment.

Engineers.-The Trans-Caspian sapper company has been replaced by a sapper battalion of 3 companies, 1 of which is a telegraph company. The Turkestan sapper half-battalion has become a battalion of 4 companies.

The 14th, 15th, 16th, 17th, and 19th European Sapper Battalions have been provided with telegraph companies, and have now each 4 companies. Two new miner companies have been created in the Amur military district; 1 company is for the defence of the mouth of the Amur, the other is located at Novokijevskoe, in the Bay of Posjct.

vol. XIII. 
A n'w fortress balloon section has been formed at Jablonna, near Warsaw. A fortress telegraph section has been formed for Vladivostock.

Inspection in Feld-firing.-A new development in the training of the troops was tried at the camp of Krassnoe Selo with such good results as to lead to the anticipation that the procedure followed may be generally adopted. The exercise was in the first instance in the nature of a manouvre with opposing forces of all arms, and it took its course until a defensive position having been taken up by the one force, the commander of the other force had reconnoitred this position and issued his orders for its attack. The situation was then marked by flags, and the attacking force marched back to camp, while the force on the defensive put out targets to represent its dispositions before it returned to camp.

The following day the attack was carried through by the attacking force with shell and ball ammunition, the defenders being formed up in the vicinity outside the sphere of fire to witness the results.

Training of Infantry and Cazalry in Artillery Exercises. - A great extension has been given to the training of officers, non-commissioned officers and men of the other arms in the service of field and horse artillery guns. During the past three years this training has been confined to men of the guard infantry and cavalry. Last summer it was extended to non-commissioned officers and men of the 24th Infantry Division, and the programme was so far enlarged as to include the training of noncommissioned officers of the cavalry and the 24 th Infantry Division to act as No. 1 of a gun. The officers commanded sections. On the 22nd July, 3 foot batteries and a horse artillery battery of war strength composed in this manner were inspected by the Grand Duke V'ladimir.

\section{SwITZERLAND.}

Field Army'-With the exception of the sanitary train and of companies of position, which are furnished from the Landwehr, the field army was formed entirely of troops belonging to the Auszug. These are composed of the yearly classes between the ages of 20 and 32 .

The units are numbered throughout the 8 divisions or 4 army corps.

The infantry and engineer companies (with the exception of the telegraph companies), the artillery regiments and mountain batteries and some variations in the larger bodics are exceptions to this rule. Each army corps consists of 2 divisions each of 2 brigades, and comprises 8 infantry regiments numbering 24 battalions (the 1st Army. Corps has 23, the 4th Army Corps 22 battalions only), 2 of which are rifle battalions; 1 cavalry brigade of 2 regiments each having 3 squadrons, and $2 \frac{1}{2}$ companies of guides; 2 units of divisional artillery and 1 of corps artillery, each of 2 regiments of 2 batteries, and 1 corps park; 2 half-battalions of engineers, 1 field bridging detachment, and 1 telegraph company; 2 divisional and 1 corps field hospitals, having together 10 ambulances; 1 corps supply establishment and 2 administration companies; and 3 cyclist sections.

There are further, unalloted to army corps, 1 company and 2 halfcompanies of guides, 1 regiment of 2 batteries mountain artillery, 
$3 \frac{1}{2}$ formations of artillery of position comprising 14 companies, 1 railway battalion, 2 ambulances, and 1 cyclist section.

Garrison Troops.-The garrisons of the St. Gothard and St. Maurice are composed as follows:-

St. Gothand-Infantry.-2 battalions of Auszug, 2 regiments and 1 battalion of Landwehr.

Artillery.-2 fortress companies, 1 unit of artillery of position, composed of 2 companies each of Auszug and Landwehr, 1 field artillery battery of Landwehr.

Engineers.-4 companies of sappers of Landwehr, 1 telegraph company Landwehr, 1 ambulance Landwehr.

St. Maurice-Infantry.-1 battalion Auszug, 1 regiment I andwehr.

Artillery.-1 fortress company, 1 mountain battery Landwehr, $\frac{1}{4}$ a unit of artillery of position, composed of 2 companies, 1 each of Auszug and Landwehr.

Engineers.-1 sapper company Landwehr, 1 telegraph company Landwehr, 1 ambulance Landwehr.

As a security against a coitp de main before the mobilisation of these troops has been completed permanent guards are cmployed.

Landwehr.-This category includes all men from their 33rd to their 44th year of age. They can be employed either to reinforce the field army, or as garrison troops, or for territorial duties. Its units have, with some exceptions, the same composition and numbering as its corresponding units of the field army. In consequence of the garrison troops being separated from the rest, the $2 \mathrm{nd}$, 7 th, and 15 th Brigades were broken up, and the $3 \mathrm{rd}, 13$ th, and 30 th Regiments were allotted to the 1st, 8 th, and 16 th Brigades as 3 rd regiments, and the 4 th Rifle Battalion to the 16 th Regiment in the place of the 47 th Battalion.

Of the 8 park columns, 2 are located in each of the four park depots, at Thun, Berne, Lucerne, and Schwyz.

Consequent upon the above there remain available for strengthening the field army, or for further cmployment on fortress or territorial services, the following Landwehr formations:-

Infantry:-10 brigades of 2 regiments of 3 battalions, and 3 brigades of 3 regiments of 3 battalions, 7 rifle battalions.

Cavalry.-24 squadrons dragoons and 12 companies of guides.

Artillery. -7 field batterics, 1 mountain battery, 5 companies of artillery of position (crsatz reserve), 2 ordnance companics, 16 train sections.

Enginecrs.-11 companies sappers, 2 field bridging sections, $2 \frac{1}{2}$ telegraph companies, 4 railway companies.

Sanitary.-16 ambulances, 3 sanitary trains, 5 transport columns, 8 hospital sections.

Administration.-8 companies.

Territorial Troops. - In addition to such Landwehr formations as may be left available for the purpose, the Landsturm comprises all males fit 
for service between the ages of 17 and 50 years, who are not enrolled in the Auszug or Landwehr.

Strength.-The following table shows the establishment on the 1st January, 1897:-

\begin{tabular}{|c|c|c|c|c|c|c|c|c|c|}
\hline 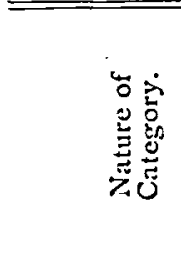 & & 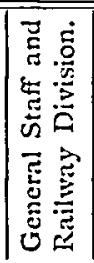 & $\underset{\stackrel{\vec{Z}}{\vec{E}}}{\stackrel{\dot{E}}{E}}$ & $\frac{3}{3}$ & 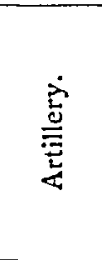 & 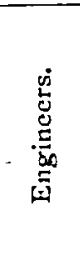 & 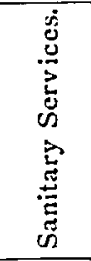 & 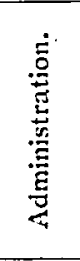 & 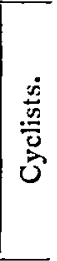 \\
\hline Auszugr & $\ldots$ & 60 & 105,512 & 3,972 & 21,803 & 6,209 & 5,053 & 1,591 & 245 \\
\hline Landwehr ... & $\ldots$ & 42 & 58,528 & 3,261 & 12,511 & 3,849 & $3,4 \geq 8$ & $S 55$ & - \\
\hline
\end{tabular}

\begin{tabular}{|c|c|c|c|c|c|}
\hline Landsturm. & Fusiliers. & Rifles. & $\begin{array}{l}\text { Artillery of } \\
\text { position. }\end{array}$ & Pioncers. & Auxiliaries. \\
\hline Officers & 1,669 & 123 & 101 & $6 S 8$ & - \\
\hline $\begin{array}{l}\text { Non }- \text { commissioned } \\
\text { Officers } \quad \ldots \quad \ldots\end{array}$ & 6,257 & 446 & 470 & 1,531 & - \\
\hline Men ... & 40,877 & 3,187 & 2,372 & 100,015 & 110,518 \\
\hline
\end{tabular}

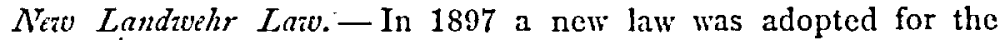
regulation of the infantry. Thirty-three battalions, of the 1st lev;, are to be formed from the fusiliers passed to the Landwehr from the 96 fusilier battalions of the Auszug, and 1 rifle battalion of the 1st levy from the riflemen passed from each two rifle battalions. For this purpose the 7 annual classes from the 33rd to the 39th year of age inclusive are employed.

Subaltern officers are liable to serve with the battalions of the 1 st levy until the completion of their 44 th year of age, but they may be transferred earlier to the 2nd levy. Equally, supernumerary officers of the Auszug maj be transferred to serve with the 1st levy battalions of the Landwehr.

Regiments can be formed of from 2 to 4 of these battalions, and brigades of from 2 to 3 regiments, which can be attached to army corps as necessary. The classes between 40 and 44 years of age, which are the five oldest classes belonging to the Landwehr form the 2nd levy and furnish, equally with the 1st levy, 33 battalions, with an establishment to be fixed by the Bundrath. Provision is made for forming the battalions into regiments, but no brigade organisation is contemplated for these formations of the 2 nd levy.

The numbering of the battalions is the same in both levies. It begins with 101 , so that as a rule the Landwehr battalions have the regimental number of their battalions of the Auszug plus 100 . 
Artillery and Train of the Landzeltr.-As with the infantry battalions, so also with the previously existing 8 field and 2 mountain batteries of the Landwehr, it was decided that sufficient value was not obtained from the organisation in force. At the same time it was recognised that the park columns and ordnance companies of the Auszug could be furnished without difficulty by the Landwehr.

From the 1st January, 1898, therefore, the 16 park columns and the 2 ordnance companies of Auszug were disbanded, as were in the Landwehr the 8 field and 2 mountain batteries, the ersatz reserve of the artillery of position, the train sections of unequal numbers (1 to 157) and the 2 ordnance companies.

From the same date there were newly formed : 8 ficld batteries (Nos. 49 to 56) and 2 mountain batteries (Nos. 2 and 3) for the Auszug, and for the Landwenr 16 park columns (Nos. 1 to 16), 4 staffs of park depôts (Nos. 1 to 4 ), and 8 park depót companies (Nos. 1 to 8), 4 park columns (Nos. 1 to 4), 5 companies of position (Nos. 11 to 15), 5 transport companics of position (Nos. 1 to 5 ), 4 sanitary transport companies (Nos. 1 to 4), 1 train division (No.9), and 8 train detachments (Nos. 1 to 8 ).

The divisional and corps artillery form each 1 regiment of 2 divisions; in the divisional artillery each division is of 2 , and in the corps artillery of 3 batteries.

The previously existing 2 mountain batteries are renumbered 4 and 1 respectively. The 4 mountain batteries will now form, with the 4 park columns, a mountain artillery regiment.

The re-organisation includes an increase to each company of artillery of position of 2 officers and $46 \mathrm{men}$, which brings its strength up to 8 officers and 162 men. The establishment of guns is augmented to sixteen 12-centimetre guns, twelve 12 -centimetre mortars, and twelve 8 -centimetre guns, in all 40 guns. Each of the 5 divisions of artillery of position is formed, from 1st January, 1898, of 2 companies Auszug, 3 companies Landwehr, and 1 transport company Landwehr. Hitherto the companies have been formed 1 from each canton, but they are now to be composed of the men passing into the Landwehr from the field batteries in the proportion of 1 company from groups of from 4 to 6 field batteries, which in part belong to several cantons.

The ammunition park of an army corps will be formed entirely of Landwehr. It is composed of a mobile corps park and a park depot, the former consisting of a staff and 4 park companies, each with 16 twohorsed infantry ammunition wagons and 14 four-horsed artillery wagons and store vehicles; the latter of a staff and 2 park companies.

As regards the train, the sanitary transport company of an army corps is composed of the officers and men of the transport of the divisional field hospital and the corps field hospital, and also of the ambulances of the Landwehr. It is supplied from the men of the second unit of corps artillery who pass from the Auszug.

The previously existing 8 Iandwehr sections of even numbers ( 2 to .16) are renumbered from 1 to 8 , and the new 9 th section is formed of 
men of the line train of the corps establishments passing from the Auszug. The odd numbers (1 to 9) provide for the horsing of the sanitary transport companies; the even numbers ( 2 to 8 ) augment the supply trains for the eventuality of the 1st levy of the Landwehr infantry being embodied in the army corps. The line train of divisions provides in the Iandwehr the line train of the battalions of the 1 st and 2 nd levies; the men remaining over form a train-detachment by divisions, which bears the number of the division concerned ( 1 to 8 ) and is available for mobilisation and etappen services.

Garrison Troops.-The re-organisation of the artillery and Landwehr infantry has led to the following modifications :-

Fortriss Troops of the St. Gothard.-Two fortress artillery divisions; Nos. 1 and 2, each composed of from 2 to 3 sections, each with 1 machine guns. One fortress company (No. 1).

Forlress Troops of St. Maurice.-Ones fortress artillery division, No. 3, with staff, 2 guniner companies, 1 observation company. One machine gun company, No. 3 , of 3 sections, each with 4 machine guns. One fortress company, No. 3.

The Landwehr men of these fortress troops form the Ersatz reserve for the Auszug, and are not therefore always formed in separate units.

Ersatz Troops.-For 1897 there were 18,680 recruits raised for the ersatz service, of whom 16,036 were exercised in 1896 .

They were distributed as follows:-Infantry, 15,206; cavalry, 557; field artillery gunners, 344 ; field artillery train soldiers, 510 ; mountain artillery, 120; fortress artillery, 245; artillery of position, 221 ; train, 446 ; engineers, 411 ; sanitary service, 479 ; administration, 141.

\section{Tire South African Republics.}

1st.-The Transzaal.-According to the latest advices, the white population numbers 205,397 , of whom 137,947 are males and 107,450 females. There are besides 622,544 Kaffirs $(123,320$ men, 159,966 women, and 334,280 children).

The number of burghers liable to military service is 26,500 , of whom 14,259 are between 18 and 34 years of age, 8,152 between 34 and 50 , and 4,089 under 18 or over 50 .

Since 1895 the State artillery has been completely re-organised, This corps is to form the nucleus of the armed forces of the republic, and it must always be ready to march. Its military training is to be so regulated that at the termination of their period of service the men may be prepared, if necessary, to act as non-commissioned officers.

The corps, of which the commandant general is the chief, consists of 1 coloncl-commandant, 1 major (who is destined to lead the artillery in war), 2 artillery captains, 1 captain-intendant, 5 artillery 1 st licutenants, 1 Ist lieutenant as adjutant to the colonel, 1 1st licutenant of the field telegraphs, 1 surgeon (1st lieutenant), 12 artillery 2 nd lieutenants, 1 quarter- (and pay-) master (2nd lieutenant), 1 veterinary surgeon (2nd lieutenant), 1 bandmaster (2nd licutenant), 8 non-commissioned adjutants 
of artillery, 1 licutenant of field telegraphy (superintendent), 1 lieutenant of Army Medical Department (apothecary), 1 lieutenant of workshops (superintendent), 5 sergeant-majors of artillery, 1 sergeant-major of field telegraphs, 1 trumpeter-major, 5 quartermaster-sergeants of artillery, 20 artillery sergeants, 3 field telegraph sergeants, 1 hospital sergeant, 30 artillery corporals, 3 ficld telegraph corporals, 1 commissariat corporal, 1 tailor, 1 saddler and shocmaker, 226 artillerymen, 28 apprentice telegraphists, 4 men of commissariat, 18 musicians, 11 sick attendants, and 6 apprentice shoeing-smiths.

The number and patterns of the guns are not accurately known. An earlier communication gave 6 light and 6 heavy Krupp guns, 4 light and 2 heavy quick-firing guns, 1 rifled muzzle loading gun, and 1 machine gun. But various purchases of guns have been made in recent years. In his last annual report the commandant-general reported two 6.:centimetre Krupp guns, with ammunition, had been made over to the Volunteer corps at Krugersdorp for practice purposes, and that an 8-centimetre Krupp gun had been received in the store at Pietersburg.

Volunteers.- In order to encourage the love of arms and shooting exercises a law was passed in 1894, authorising the constitution of an infantry or cavalry Volunteer corps, provided in any place at least 50 burghers desired to form one.

Already in 1892 and 1893 a corps had been formed consisting of an infantry formation of $100 \mathrm{men}$, and a cavalry one of $110 \mathrm{men}$, with 4 combatant officers each.

A corps raised at Johannesburg in 1896 consists of 2 infantry battalions, one of 3 , the other of 2 companies, 2 cavalry squadrons, a ficld telegraph detachment, and an ambulance section. 'The whole corps of 600 infantry and 200 cavalry is under a colonel.

Krugersdorp has a cavalry corps, about 150 strong.

In 1896 corps were constituted at Middelburg, Carolina, and Ermelo.

The Orange Free State.

The number of men liable to service is about 20,000 .

The permanent troops consist of the corps of field artillery, of about $80 \mathrm{men}$, and is stationed in the fort at Bloemfontein.

There is a reserve of about 400 men.

The armament is composed of 14 Krupp guns of $7 \cdot 5$-centimetre, 5 Armstrong 9-pounders, 2 Whitworth 6-pounders, 1 Whitworth 3-pounder mountain gun, one 3 -centimetre Krupp gun, and 3 Naxim guns.

\section{Infantry ThCtics ANd the Eurloyanent of the Commined Arus.}

A work by General von Schlichting, entitled "Taktische und strategische Grundsätze der Gegenwart," which was published last year, forms the basis for the discussion of an interesting point of tactical procedure. It refers to the withdrawal of company supports (the "petits paquets" of the French), and, in connection with this, to the extension of entire companies of a battalion from the outset. 
This is provided for by the regulations in France and Russia (provisionally), whereas in other armies the small supporting bodies still play their part.

General von Schlichting advances the following grounds for the latter procedure:- "The company on a war strength, after it has been extended, is no longer in the hands of its leader when working over ground in touch with the enemy. The premature extension of the entire unit promotes this tendency, which was in time excluded, as being so objectionable for fighting in extended order. In varied ground one wing may be brought to a standstill by the opportunity of producing a favourable fire effect, while the other advances as ordered; between the two, imagine the company leader, who will have dismounted, at this time maintaining the unity of his command. Upon entering on the fight an extension zug by zug recommends itself-if at all practicable-especially as a change will have to be made in direction in the majority of cases, at first in most, and small deployments will enable this to be most easily effected. There must be new men at hand to fill the gaps, and maintain the intensity of fire at an equal degree. It is all very well to preach that small closed bodies behind the firing line are receptacles for bullets, and will suffer losses, without at the same time making any preparation, in the event of being afterwards obliged by the procedure adopted, to place other battalions behind those which are fighting entirely extended."

The French regulations advance the following reasons against the extension by successive portions:-"The supporting bodics are not sheltered from the fire directed upon the firing line in their front, and suffer losses, without themselves being able to take part in the fighting. The company when broken up is in part no longer under the immediate leading of the captain. The subordinate bodies may come under the orders of inexperienced leaders, who will not always handle them properly, and will allow the proper moment for their advance to pass. Lastly, the pushing up of reinforcements produces the premature intermixture of units, it makes leading diffeult, and acts detrimentally upon the good delivery of fire."

The Russian regulations (provisional) justify in the following terms the elimination of the company reserves when working with the battalion :"It is necessary to bring into action the greatest number of rifles possible, to place from the first the conduct of the fire in the hands of the experienced company leaders, and to minimise the losses, by withdrawing from exposure to hostile fire the generally uscless supporting bodies. By the extension of entire companies (the provisional regulations lay down that in normal conditions two whole companies are to form at first the firing line, and the remaining two the battalion reserve), the battalion commander has for the time two formed companies under his hand, whereas with the system of small fractions he has perhaps one intact company at his disposal, but often only the supports will remain availablo as reserves, which does not suit him at all, for they are under the company commander who is in front."

Other reasons could be added to these, amongst them the ballistic 
consideration, that three echelons of troops (firing line, supports, and reserve companies) pressing closely upon one another in a comparatively restricted space, will suffer greater losses both from artillery and infantry fire than two echelons (firing line and reserve companies) occupying an equal space.

Equally, greater simpiicity cannot be denied this formation, and, as regards simplicity in tactical procedure, the late General von Schachtmeyer has strikingly remarked :- "True tactical wisdom lies in simplicity, which spares the tactical mediocrity, with the pain of choice, much embarrassment."

If one considers the divergent views that exist, even on the parade ground, about the position of the supporting bodies, their distance from the skirmisher line, and the manner of their advance, and takes also into considoration the inherent weaknesses ballistically of this formationwhich may 25 years aggo have been quite practicable-it must be recognised that its days are numbered.

It is interesting to note the statement of an adherent of this formation, who has written:- "It is impossible for supporting bodies in cluse order, with two ranks, to advance under uninterruptedinfantry fire at close and medium distances." (" Einleitung und formale Talitik der Infanterie," Captain von Balck. 13erlin, 1897.)

The defenders' infantry fre at medium distances will be almost alway's uninterrupted. The supporting troops should contribute towards interrupting it; but if at medium distances-from 1,000 metres-they are impossible, they lose the advantages claimed for them (reinforcement of the shirmisher line, and reservoir for this).

They must, therefore, follow with rank entire or with opened ranks; but of this, in Germany at least, the adherents of small bodies as supports will not hear. There is then, tactically, a vicious circle amongst the friends even of the "petits paquets," and, therefore, the two most recent regulations-the French and the Russian-seem to have taken the right course in putting an end to it.

As regards the system of scouts (éclaireurs in France and okhótniki in Russia), its fundamental idea is no doubt tactically correct, in so far as it allows of the deployment of the skirmishing line for the purposes of security and information taking place as late as possible, which is always an advantage from the point of yiew of leading. But owing to the exaggerations of this system, as practised in France, its value has been affected. The arrangement by which a thin screen of patrols is pushed forward until the distance from the encmy is reached at which the fighting of the advanced skirmisher lines begins, can only contribute to secure the first deployments and carry them out more quietly.

The infantry fight requires above everything quict in its preparation and first development. It is a dangerous deception to judge of the tactical skill of a leader and the tactical capability of a body of infantry from an impulsive and smartly engaged fight. True smartness and enduring energy only show themselves in the carrying through of a fight ; 
but before the infantry is so far, before it is really engaged, a tactical organisation must be arranged quite quietly, which shall ensure unity and endurance of effect.

In the past year the conviction scems to have gained more ground in infantry circles, that our tactical training must be based on the conflict of masses and not on mere engagements. This does not in any way exclude the greatest care being devoted to the training of the infantry soldier in fighting alone, but battles are not won by means of such fighting nowadays.

But the so-called "Auftragverfahren," or the giving of general instructions, leads to isolated engagements. Writing of the system in his "Betrachtungen ïber Heerwesen und Kricgführung" (Berlin, 1897), Lieutenant-General von Boguslawski expressed himself in the following terms:- "Far be it from us to dispute that such a procedure may, especially in the case of a single battalion or regiment, be quite sound. But it seems to us wrong to erect it into a principle, to an exclusive method.

"We think that for any oflicer who has fought in great battles as an infantry soldier this must be patent. We would ask then where the instructions for battalions and companies come in.

"In the great majority of cases the affair will develop in such a manner that the commander of the regiment or the battalion deploys his troops in such a direction and in such a manner as to leave no doubt. If time admits of it, he states briefly the object of the engagement, gives a point of direction or himself leads a fraction which is followed by the rest, orders the formation of the whole and moves forward. In such a case what is the good of giving independent instructions, which occupies time, and often opens the door to misunderstandings?"

It may be added that it is much easier generally to give indefinite directions than a definite order. The oflicer who gives an order undertakes a greater responsibility than the one who gives directions only, and who, if things go wrong, will be inclined to seek for the fault in a false appreciation of his instructions.

Instructions may often be appropriate for cavalry and artillery; but seldom for infantry, at least, in bodies from the brigade downwards.

In any case, orders which say neither too much nor too little will contribute towards making a certain unity in the handling of the troops more possible than if they were operating under instructions only. But the infantry is the worst of all the arms as regards the unity and lucidity of its tactical action, and therefore the effort to limit tactical friction as far as possible rather than to increase it seems justifiable. The war machine, which has to overcome the inevitable friction of battle as best it may, cnsures by this means a main chance of victory. A regiment or a brigade which is accustomed to work by order in the first stage of the fight, makes even in peace a more certain impression. It is said to be in the hand of its commander. But whoever understands by "orders," on the battle-field, the more or less mechanical importation of drill-ground customs will undoubtedly suffer tactical shipwreck before the enemy. 
The reader will, perhaps, have asked impatiently already when he is to hear anything of the actual fighting of infantry; of fire tactics. But this latter is not a thing standing by itself, but it is rightly appreciated in the closest connection with the preparatory measures for the actual fight, which is one of massed fire, and the tactician who is in a position to create the most farourable conditions for this massed fire-fight stands on the pinnacle of capacity. But this is naturally only to be attained by skilful arrangements for the march, deployment and engagement of the infantry masses. Higher tactics thus dictates the law to lower tactics.

Only, therefore, so much room should be given to detail as it deserves. All the science of infantry fire, all the individual training, are of no avail nowadays, unless the tactical leading understands how to combine them for a skilful, powerful effect.

It will seem to many that General von Scherff ("Die Lehre vom Kriege anf der Grundlage seiner neuzeitlichen Erscheinungsformen." Bcrlin, 1897), especially by laying down tactical conditions for the attack of infantry, here and there in his philosophical formal demonstration goes beyond the living changing effects of the fight; but the substance of his demands to banish the arbitrary, the subjective, as far as possible, from the procedure of the fight, appears to many to be justified. Rules cannot be prescribed for the leading of the troops, because this depends chicfly upon the personality of the leader. But what in normal conditions the procedure of the infantry will be in the fight can be reduced as well to-day to a definite technical method, as has at all times been possible. The use of the skirmisher swarm need not alter this. However this may be, in any case a growing re-action is becoming international against the so-called free procedure. This is cvidenced not only by numerous literary expressions of opinion, amongst which are some of weight, but also by the direction taken in the latest regulations.

The requirements referred to must not be taken as being refuted by the sentence "superiority of fire is to be obtained by appropriate ways of leading," so far as an attack over ground more or less wanting in cover is concerned. Amongst these ways of leading are to be understood secondary methods, such as threatening the flanks, superior artillery effect, the production of concentric fire effect, the employment of the spade, of the night, etc. It is certain that the modern fight can afford less to dispense with such methods than formerly, but they will not absolve the infantry from the frontal attack of strong positions under difficult circumstances. The frontal attack of infantry forms on the contrary, as military history teaches, the substance of battles. Even the enveloping attack comes eventually to be a frontal one.

The entire modern tactical development tends towards the creation of a method of fighting which will support it in.its difficult task.

In the controversy on this subject also too much stress must not be laid on the losses that might be incurred. At the time of the Silesian wars the effect of fire on attacking infantry was in its final results much 
more dreadful than it is now. But no one thought, on this account, of declaring the frontal attack of infantry a failure.

In France, as also in Austria and Russia, volley-firing plays a great rôle by the regulations. It was pointed out in the 1896 reports that objections had been raised to this preference for volley-firing, which recall too much the drill ground. It is claimed by its adherents that the leader who keeps his troops well in hand has a great advantage, and it will enable him to continue this method of firing. This is quite true, but the difficulty is to keep them in hand, looking to the many disturbing and disintegrating influences of the modern fight.

The principle of firing volleys is more or less based upon the retention of the troops in formations which generally appear not to be applicable in real war, on ballistic grounds, and upon their regular execution at medium distances, which will not be realised for psychological reasons. Exceptionally volley-firing may be applicable, but the future belongs to quiet individual fire, supported, and as far as possible influenced, by fire-leading and fire-discipline.

During the past year a re-action has also made itself felt in France against the principle which has been maintained there of late, that infantry fire should only commence at the limits of medium and close distances. In Germany, a short time ago, this theory had many adherents. In recent years, however, a change has been noticeable.

A French officer of reputation, General Philebert, has discussed this question (1, "L'Instruction du tir" ; 2, "L'Infanteric perd son temps," Paris). He writes:- "It is said that good troops must approach as close as practicable to the enemy before opening fire. That is no doubt a good idea, but it would be as good a one to say to a poor devil who is dying of hunger, Be rich!

"Is it possible to open fire first at 600 to 700 metres? Is it credible and probable that men will march under rifle fire without replying to it? We do not believe it, and are strongly of opinion that fire draws fire, and that those who have to suffer from fire will reply to it. It may be fatal, but it lies in the nature of things.

"At all times, fire has been commenced at long distances, even when the range of the bullet did not exceed 200 metres. At the present time, when the rifle is effective at 2,000 metres, much time will be required to approach to from 500 to 600 metres; this is certainly not agreeable, but it cinnot be altered."

The new Russian Infantry Drill is still regarded as provisional. As regards the method of attack, it occupies a middle place between the "free" procedure of the German pattern, and the normal dispositions of the French regulations.

In the first place, the distinction made in the German regulations between the rencontre battle and the attack of a prepared position is not adopted. The procedure is based on the ranged battle. This seems appropriate, first, because the fighting formations and the procedure of the infantry are the same in the rencontre engagement as they are in the 
planned attack-it is only the employment of the troops that differsand consequently the regulations do not need to make any difference in this direction. Secondly, rencontre battles are more or less exceptionaloften not desired-and regulations should not make provision for exceptional cases. Thirdly, the rencontre engagement only makes exceptional measures necessary for the foremost troops; the main body of the infantry, which has to carry through the actually decisive fight, is unaffected by it.

As soon as touch is established with the enemy, if it be not found possible to gain a clear knowledge of his situation, the advanced cavalry" bodies are to be reinforced by the "okhótniki" of the forcmost battalions -1 officer, 4 non-commissioned officers, and 16 selected and specially trained men per battalion.

The deployment of the infantry will take place in open ground at from 2 to $2 !$ versts from the enemy, or if he has artillery, at about 4 versts.

There are two phases in the attack that are particularly emphasiscd:-

1. The advance as far as the decisive fire position.

2. The assault on the enemy's position itself.

$U_{p}$ to effective range, which for the defenders is taken to be 2,000 paces, the companies of the fighting line move, preceded by a thin skirmisher veil, in ranks, with sub-divisions on the same alignment, or in line. On getting within 2,000 paces skirmisher lines are formed bythe fighting line, which continues to advance quietly and uninterrupted. Firing is only permitted at especially favourable objectives at this period. At from 1,400 to 1,000 paces firing becomes general. At this distance all the portions of the force destined for the attack must be drawn up on the proper front, because it is then impossible to move them into it.

The skirmisher line is gradually reinforced. Its further advance is carried out as far as practicable at a walk, either by the whole line together or by successive portions. The decisive firing position will be taken up at from 400 to 500 paces from the enemy. From here the decisive assault is made by the reserves, which have come up in the meantime, combined with the skirmisher line. If it is by any means possible a battalion or company is placed on one flank to enfilade the enemy.

The principle laid down in the Russian regulations, that the skirmisher line, as well as the rest of the troops destined for the attack, should make a continuous advance at a walk up to from 400 to 500 paces from the enemy, may be called in question from a tactical point of view.

If the ground permits of this procedure, so much the better for the attacker, who has to do with so stupid an opponent, who selects such favourable ground for the attacker. In the plnins of Eastern Europe protection of this nature from the ground is seldom to be met with. And again, tactically, objection must be raised to fire 
position being fixed at from 400 to 500 paces of the enemy. In the Dutch regulations (equally of recent date) it is fixed at 700 metres, nearly double as far from the defender as the Russian. I believe practice will indicate it as from about 600 to 700 metres.

In spite of these cchoes of shock tactics, the Russian regulations contain a very great deal that is sound respecting tactics, and much that is worthy of imitation in regard to the formations and distribution of infantry for the fight.

\section{The Action of the Cominined Akms.}

Referring to the Kaiser manocuvres in Germany in 1897, the most noticeable tendency of the East Army was to avoid the strategy of detachments, and to enter the fight "massed," which was of "great value to the tactical energy.

On the first day of the mancuvres a rencontre fight took place, when the great advantage to carrying it through of endeavouring to gain the objective by bringing the forces into action as simultaneously as possible was exemplified. The re-establishment of the fight by forces held back at first involves in war the more consideration, because peace manœuvres often offer a picture as regards this point that is altogether unreal.

When a body of troops is pushed back by superior forces, it implies nowadays a much more intense moral shaking than formerly, because the effect of the firc by which it is followed up is more intense. Such a body of troops is tactically of very little value afterwards.

If fresh forces now come into play, they can hardly be in a position to re-establish the lost moral firmness of the defeated main body. But in manœuvres such "partially defeated" troops are frequently treated again in a short time as nearly equally" valuable tactical factors, however powerfully they may have been shaken. If now the troops that have been held back are brought into action, the principle of the last trump is applicd in favour of those who, still unharmed, continue to co-opcrate with them.

It may often not be possible to alter this procedure in peace. But it implies a certain obscuring of the tactical matter of fact, and is contrary to the principle of bringing the forces into action, as far as practicable, united and simultaneously.

The character of the rencontre fight which the collision on the first day produced, raises another point for discussion as regards the employment of the troops. It may be taken to be generally known, that the rencontre battle, such as was frequently observable in the FrancoGerman War, is not to be regarded as answering to ideal leading, for it makes the planned and united employment of the forces very difficult, even when it does not preclude it, and favours the so-called soldiers' battle. But the science of leading troops must certainly reject this latter. It need not, however, prejudice the practical science of war to refer to the rencontre battle as an unavoidable episode of modern warfare.

The fact appears to be proved by what occurred at Hanau on the 6th September, $189 \overline{7}$; for in this case a more accurate knowledge of the 
cnemy's movements may be assumed than would be the case in war. Notwithstanding this, a rencontre battle ensued ; and on closer examination another different kind of lesson may be drawn from it, which favours the opponents of this kind of battle.

In the course of the 6 th September, 6 divisions of the eastern force could come into action against 3 divisions of the western, because the latter had an army corps so far in rear that its participation in the operations on that day secmed to be precluded. In these conditions was it for the west to decide upon a rencontre battle? Would it not have been of greater advantage to give up the offensive altogether on that day, so as to avoid the danger of an isolated tactical defeat, and to fight on the day following with the forces concentrated? The stralegical grounds for adopting an opposite course, as well as the contention that the offensive always favours success, cannot refute the fact, that all strategy and cvery principle must completely fail, unless the tactical situation is such that chances of success exist. But when 6 divisions can be brought into action against 3 divisions the tactical chances of the latter are non-existent.

On the third day of the mancuvres an opportunity was given for the independent action of subordinate leaders, such as might arise in war, and such as would rightly be desired by every leader of troops. A division by the order of the army commander had made a movenent with a view to seizing a specified position. The opponent utilised the gap that resulted from the movement to get round the flank of the troops engaged in the first line. In spite of the definite order, the division - referred to at once stopped its advance, and entered the fight independently, by which means the line was preserved from being hroken through. This was real independence, which systematically and on a just consideration of the pros and cons, did not hesitate to depart from an order that had been received.

Such independence must not be confounded with what is to be understood by the term independence as applied to the subordinate leaders, down to the smallest tactical units. The same divisional commander, who in this instance was quite satisfied that the situation did not admit of waiting to deploy the division, but attacked with all available forces, would in all probability have strongly deprecated regiments or battalions acting separately on the initiative of their commanders during the execution of a planned attack.

There is only this to be added to this instructive practical example: the principle of independence can only be awarded a restricted space in the actual procedure of the battle-field, without endangering seriously the unity of the tactical handling. On the other hand, independence in the right place as an attribute of a leader, will come of itself to every intelligent officer who has character. If these characteristics should be wanting, a uniform regulation pattern accentuation of "independence" may casily lead tactically to more harm than good.

On this occasion (1897) the cyclists have taken their place at the great German mancuvres as organised troops. This organisation was 
indeed only a provisional one, and one cannot but agree with the opinion that is gaining ground, that the cyclists must be given a permanent tactical organisation as fighting troops. Undoubtedly an organisation effected when the necessity arises, or a body of men got together a few weeks previously will always be inferior compared with cyclist troops with a solid organisation, as is the case with every military improvisation.

The idea of employing cyclists as fighting troops has been scientifically supported for some years, without-except in the case of some small armies-finding general practical recognition. This is the known sorrowful history of most military noveltics. At first the right of existence was denied them for reconnoitring and reporting duties. Then the utility of their employment as fighting troops was doubted. There ought now to be an end of this doubt. Notwithstanding various entirely inaccurate reports in the Press, it must be established that the fighting cyclists repcatedly did right good service at the German manœuvres.

With the Bavarian portion of the army (east), a cyclist formation of about 100 men came into action. This was generally employed with the cavalry division. With the Prussian force (west), the scveral army corps had cyclist formations of from 60 to 80 cyclists each, which were allotted, part to the cavalry division and part to the advanced guards.

Notwithstanding that the German military cycle is rather heavy and not adapted to fold up, as is that in use in the French Army, the cyclist formations succeeded in getting on, even in difficult country and on bad roads. They were repeatedly able to act effectively in occupying defiles, preventing or disturbing the construction of bridges, holding the encmy's advanced troops; in short, making themselves generally troublesome to the enemy.

With further organic and technical development, the cyclist troops of the future will no doubt also enlarge their tactical sphere of action, but only within certain limits; and their action should apparently be of greatest value in securing the tactical independence of the cavalry.

As regards the employment of cavalry-as forming part of the combined arms-it is to be noted that in the German Kaiser manceuvres the divisional cavalry, in the middle of the front of battle, favoured by the nature of the ground, found opportunities for successful attack by surprise on the exposed flank of the engaged firing line. It may be said that these were exceptional. Still they show that smartly led cavalry will find opportunities of co-operating with the infantry, as was actually the case on that occasion; in future cavalry will have probably to pay more attention tactically, not to acting for itself only, but to endeavouring to operate in closest connection with the engaged infantry.

It is generally admitted that the employment of field artillery in masses suitable to battle tactics was almost perfect during the manœuvres in the Weterau. The conviction continues to gain ground, that in the present day the execution and final decision of the fight is principally dependent upon its preparation; and, consequently, that this preparation must be regarded as the most important stage, and not the so-called assault regarding the delivery of which everybody is racking his brains. 
This determines the great importance of the artillery, for to it falls the preparation in the greatest measure.

In connection with this, it is typical that this preparation by the artillery is no longer regarded, as formerly, as a gradual development of the intensity of the fight, but as a powerful effect of the artillery from the outset. To apply this idea sensibly to the employment of the infantry is the modern tendency of tactics, and the endeavour to give effect to it comes often into confict with those who advocate the fight being engaged directly from the columns of march. The artillery has shown for a long time the sound desire to withdraw itself from this principle, consequently there is an ever increasing departure from what was formerly the obligttory procedure of attaching artillery to advanced guards. On one of the manœurre days in the Weterau it happened also that the artillery was placed too far forward in the column; and it was not only forced to take up an unfavourable artillery position, but it found itsclf exposed to hostile infantry firc before it could be extricated by its own infantry. This happened during a rencontre fight.

On the other hand, it must not be ovcrlooked that the employment of artillery in masses in the first stage of the fight makes the question of space with reference to the infantry a difficult one.

In previous reports the tendency was noticed to recommend massed formations for the march before a battle, such as were repeatedly employed by Napoleon, but modified to suit modern requirements, as a tactical means of enhancing unity of action. Gencral Lewal first sustained this idea scientifically, basing his arguments amongst other instances on the massed advance of the 2nd German Army on the 18th August, 1870. General von Scherff came to similar conclusions in his well-known "Kriegslehren." General von Schlichting, however, rejects this procedure in his latest work, in which he writes:- "The movement of masses of troops larger than a brigade in assembly formation is no longer practicable on any ground. The return to column of march will then as a rule be advantageous."

General von Boguslawski supports the Lewal-Scherff view of this tactical disputed point, and proposes a definite mass formation for the advance of a mixed division. He says:- "It seems to us undoubted that the corps and divisions of an army accustomed to such mass formations can be more easily led and handled by the supcrior commander than troops that always move in long columns on the roads, and only form up when their heads are struck by the first bullets. 'The superior commander must always be conversant with the picture of the different formations, and, above all, he must not be prejudiced by the idea that in war marches of approach can only seldom be effected in such formations."

The tendency to march in widely separated columns should be restrained. Theoretically this course can be justified; the columns march separatcly with a view to attacking simultaneously. In war it has often failed on account of friction, which forms the rule rather than the exception. At the mancurres (1897) in Moravia, the turning column 
arrived too late, for the counter-attack had been delivered by the defenders before it could make itself felt.

This example contains much that is instructive, not only in the tactical separation, but also in regard to the employment of the main reserve. Had the defender on this occasion followed the frequenty quoted principle, that a reserve must be kept in hand to the last, he would naturally have retained his reserve intact to meet the attack of the enemy's turning column. In such a case the result would probably not have been in his favour, for a defender who is turned seldom succceds in escaping from the tactical trap. By the early action of his reserve the defender in this case gained the victory:

By following this principle of keeping a reserve in hand to the last, a complete defeat is in some circumstances avoided; but by such false economy the chances of a decisive victory will be more often destroyed. It will therefore show a juster appreciation if the leader does not choose that principle as his tactical rule of conduct, but at the right moment puts his last breath into the decision.

\section{Cavalei Tactics.}

The extent of the action of cavalry in a battle, which has been freely discussed in German military literature, must be limited at the cmployment of cavalry masses against hostile infantry and artillery in the course of a battle. Cavalry duels in advance of the front or on the flanks will not be affected by the development of the effect of firearms, which forms the crux of the question.

Small bodies of cavalry, such as squadrons and regiments, which only require a small extent of cover for their preparatory position, and a small amount of space and time for their deployment will be able now as well as formerly to utilise a temporary exposure of the enemy at a point of the line of battle by rapid surprise. The threatening of unshaken infantry on its flanks, charging shaken infantry after abandoning a position or after attacking unsuccessfully, the rolling up of a flank of artillery that is en l'air, disengaging its own infantry or artillery when hard pressed, are affairs of the moment, the suddenness of which must lessen the effect of hostile firc, less for technical than for moral reasons.

It is different as regards the employment of cavalry masses in the modern battle; but this question seems to affect only the training of superior cavalry leaders. The local distribution of cavalry masses upon the development of the battle must be based in each instance on the operations that have immediately gone before, and on the suitability of the ground.

At the German Kaiser mancewres in 1896 and in 1897, the ground on which the flanks of the infantry of the opposing forces rested excluded the cavalry being placed in the prolongation of the front, and they were behind it.

But in such conditions where the cavalry masses are first placed, there they will generally have to act; distance precludes great move. ments to a flank during the changing course of a battle. 
A cavalry division in a preparatory formation suited to the ground will occupy as a mean 600 metres in breadth and 200 metres in depth. How near it can approach in this formation within the hostile sphere of fire, without its fighting power suffering prematurely, is a matter its leader must judge of by his previous practical study of the effects of fire, that is, by observation of field firing by the other arms in service conditions.

What space will be required for the deployment of a cavalry division for its attack on hostile infantry or artillery cannot be gencrally determined. It depends upon the measures taken by the enemy to meet it, and upon its own rapidity. In no case, however, should the space required and the time for traversing it be under-estimated. These considerations relegate the possibility of surprise by cavalry masses to a lamentably but unavoidably small chance, and make their intervention in the course of the battle exceptional.

But their success in the fulure is not questioned by anyone, always provided the passing favourable moment is utilised at the right time. The experiences of the last war (Kunz, Major a.D., "Die deutsche Reiterei in den Schlacten und Gefechten des Krieges von 1870-71." Berlin, 1805) and the lessons offered by the constantly progressing effect of modern firearms, seem to point to the necessity for the thorough training of cavalry leaders during peace, the practical testing of which must be amply provided for by peace exercises.

The spirit of the new cavalry regulations that have been introduced during recent years points to the separation of the cavalry from interventinn in the artillery and infantry fight.

' he omissions and mistakes in the employment of the horse artillery belonging to cavalry imposes upon the supcrior commander a closer acquaintance with the working of this auxiliary arm.

However praiseworthy may be the initiative of a shilful artillery commander, the cavalry leader ought in no circumstances to foregro the disposition of his batteries according to his own views.

\section{Fieli Artilleky Tactics.}

The past year has at last brought a decision regarding the important question of the arming of field artillery, which since the introduction of smokeless powder-that is, for the last eight years-has occupied the thoughtful officers of this arm more than any other.

"The new gun is a compromise between the adherents of a greater fire effect and those who adrocated greater mobility. It is due to the advance made in technical art that a gun has been constructed which combines both greater effect and increased mobility, as compared with the old one.

As soon as the question of the pattern of the gun of the future was decided, that of its tactical employment came into prominence. The new gun combines a greater effect of the single shot with a greater state of preparedness. The question of its employment, and of the organisation of the ficld artillery, which is closely connected with this, can be answered in two ways, according as greater value is attributed to quict, well-directed fire, that is, to the effect of striking the target or to a sreater 
quantity of rounds being fired in a short time-that is, to the greatest possible rapidity of fire.

The advocate of quiet, well-directed fire, with observation of each shot, will desire strict centralisation in the hands of the battery leader, which is only possible with sub-division fre; this view, therefore, would point to the necessity of reducing the number of guns in a battery from 6 to 4. This alone can secure the greatest use of the power of the gun, quiet service, and sufficient ammunition supply. For in a battery of 4 guns, each gun can be provided with a greater number of rounds than in a battery of 6 guns, without an increase in the number of ammunition wagons. But if the best value be attributed to the highest development of rapidity of fire, this must nccessarily lead to a change in the method and order of firing. Some advocate the ranging being carried out as now, and after it is completed mould employ tapid fire. Others would leave the ranging to the observation of the sub-division leaders, and only fire by sub-divisions; a third party advocate the omission altogether of systematic ranging, and by means of rapid fire, would search an area of the breadth of the battery and 1,000 metres deep, on the assumption that the target within this area must inevitably be struck.

We are of the opinion, expressed here on previous occasions, that quiet and well-conducted fire should always be employed, because it leads the most quickly to the desired end, with the least expenditure of ammunition. Certainly in ranging, and afterwards, well-aimed, observed, and wellsustained (not rapid) fire is certain of its success. The effect of fire is so great, that, if ranging is properly carried out, a few projectiles will secure the destruction of the object aimed at; rapid fire then is superfluous. But if the ranging be not properly done, rapid fire is pernicious, for it consumes the greatest amount of ammunition in the shortest possible time. Rapid and dependable ranging is of much greater value than rapid fire after the ranging has been completed.

Undoubtedly a small well-trained battery (of 4 guns) will range more rapidly and accurately than a large one (of 6 guns), for it is better under the hand of its leader.

The question of the bombardment of covered objects by the field artillery has entered on a new'stage since the introduction of the new gun. This gun has, in a greater degree than the old one, the character of a flat trajectory gun, so that a high-explosive shcll fired from it would have still less effect than if fired from the old gun. The introduction, therefore, of a field howitzer, which could do good service in the preparation of the infantry attack has become much more likely.

The howitzers would be united in divisions of from. 2 to 3 batteries, and be distributed in the ratio of one howitzer division per army corps.

The important question, whether the corps artillery should continue to be organised separately as such, or permanently distributed to the divisions, is approaching a decision, for with the introduction of the new field gun a change in organisation can no longer be deferred. The number of advocates of the corps artillery has diminished steadily; for some time past they have not included any German artillery officers. On 
the other hand, General von Schlichting, in his recently published book, "Taktische und strategische Grundsätze der Gegenwart," adrocates the retention of the corps artillery. He argues that the necessity for a strong deployment of artillery generally arises in the course of the engagement, to satisfy which the corps artillery can be emplojed, "serving thus as a kind of reserve formation such as is required by the other arms for carrying through their fight." 